\title{
Investor Mood and Demand for Stocks: Evidence from Popular TV Series Finales
}

\author{
Gabriele M. Lepori ${ }^{\mathrm{a}, \mathrm{b}}$ \\ (ACCEPTED VERSION of a paper published in the Journal of Economic Psychology)
}

\begin{abstract}
In this paper I employ a novel discrete mood proxy to investigate the response of the U.S. stock market to exogenous daily variations in investor mood. Drawing upon the psychology and communication literature, which documents that the end of popular TV series causes negative emotional reactions in large numbers of television viewers, I employ major TV series finales (between 1967 and 2012) as mood-altering events. I find that an increase in the fraction of Americans watching a TV show finale on a given day is immediately followed by a decrease in U.S. stock returns. This effect is stronger in small-cap and high-volatility stocks, whose pricing is more sensitive to sentiment, and is consistent with the hypothesis that negative mood reduces the demand for risky assets.
\end{abstract}

JEL Classification Codes: G02, G11, G12, G14

Keywords: Negative mood, TV series finales, investment decisions, U.S. stock returns.

${ }^{a}$ Department of Finance, Copenhagen Business School, Solbjerg Plads 3, 2000 Frederiksberg, Denmark. I would like to thank Jacob Wallander for his help with the data collection process and participants at the 2013 annual meeting of the Academy of Behavioral Finance and Economics for helpful comments. I would also like to thank the associate editor and two anonymous reviewers for insightful comments on an earlier version of this manuscript. All remaining errors are mine.

${ }^{\mathrm{b}}$ Current affiliation: Keele Management School, Keele University, Staffordshire, ST5 5BG, United Kingdom. Tel. +44 (0)1782 733889. Email: g.lepori@keele.ac.uk. 
"In recent years the last episodes of certain long-running sitcoms have become major cultural events in American life. Record numbers of us turn on our television sets to watch what is going to happen to people who have been part of our lives for a decade or more. It doesn't matter that the people we are worrying over were invented by a team of writers [...], they're people we've grown attached to." [Mills, 1998]

\section{Introduction}

During the last ten years, behavioral finance scholars have devoted a considerable amount of attention to the role that incidental mood plays in the context of financial decision making [see Lucey and Dowling, 2005]. ${ }^{1}$ This interest has been motivated by the evidence put forward in the psychology literature that mood can affect several variables that determine financial choices, such as risk tolerance, risk perception, and how information is processed by individuals when forming expectations [Johnson and Tversky, 1983; Schwarz and Clore, 1983]. In the field of finance, empirical studies relying on observational data have employed mood proxies to measure exogenous variations in investor sentiment. Most of these proxies consist of continuous variables, such as sunshine [Hirshleifer and Shumway, 2003], temperature [Cao and Wei, 2005], and amount of daylight [Kamstra et al., 2003], while only a few take the form of discrete (zero-one) variables, such as national teams' wins and losses in sports competitions [Edmans et al., 2007] and aviation disasters [Kaplanski and Levy, 2010].

In this study, I introduce a novel discrete mood variable, the end of popular TV series, to analyze the relationships among investor sentiment, the demand for risky assets, and stock prices. This choice builds directly upon the psychology and communication literature, which suggests that television viewers experience negative emotional reactions in response to the termination of their favorite TV shows. Series finales painfully break parasocial relationships that viewers develop with TV characters over time through repeated exposure [Horton and Wohl, 1956], and given the high

\footnotetext{
${ }^{1}$ In this paper I follow the behavioral finance literature, and I employ the terms mood, affect, emotion, and sentiment interchangeably. For a review of the literature on the definitions of these concepts, see Kleinginna and Kleinginna [1981].
} 
rate of TV consumption in modern societies, finales influence the mood of large portions of the population at the same point in time and in the same direction. The empirical results suggest that a $20 \%$ (one standard deviation) increase in the number of Americans watching a major TV series finale - a proxy for the size of the negative mood wave crossing the country - is followed by approximately an 8 (25) basis point drop in U.S. stock returns the following day, which is consistent with the interpretation that negative investor sentiment reduces the demand for risky assets, all else equal. This pattern is in line with the findings proposed by Edmans et al. [2007] and Chang et al. [2012], who use sports game outcomes as mood-altering events. Furthermore, the TV show finale effect is stronger for stocks that are believed to be more sensitive to investor sentiment, which provides additional support to the interpretation that the empirical pattern I document is generated by investor mood shifts.

The rest of the paper is organized as follows. In section 1, I discuss the link between TV series finales and TV viewers' emotional state. In section 2, I investigate the relationship between incidental mood and investment decisions and present the hypotheses under investigation. In section 3, I describe the data, and in section 4 I discuss the main empirical analysis and a battery of robustness tests. In section 5, I summarize and assess my findings in light of the existing literature.

\section{Major TV Series Finales and Viewers' Emotional Reactions}

According to Tooby and Cosmides [2001], "in every industrialized society, every night after work the primary form of recreation is to immerse oneself in the broadcast or projected world of fictionalized lives and events". Since 1970, TV penetration of U.S. households has been above 95\%, and the time U.S. households spend watching TV has constantly increased from approximately six hours per day in 1970 to more than eight hours per day in 2009 [TVB, 2012]. Currently, American adults (men and women) spend about five hours per day viewing television. 
Interestingly, communication scholars argue that repeated and prolonged exposure to TV shows leads to the formation of so-called parasocial relationships between viewers and TV characters [Horton and Wohl, 1956]. Over time, TV viewers "develop a bond with the performers they see on-screen", and even if they are aware of the distinction between parasocial relationships and real ones, "they react to these familiar characters as if they are a friend or acquaintance" [Lather and Moyer-Guse, 2011]. Todd [2011] claims that fans of TV series "do not watch television, they experience it"; by following the plot developments week after week, viewers "become intimately involved in [TV] characters' fictional lives" and relate to them "as they would to real friends, discussing the characters' problems, good news, and antics over the water cooler as well as the dinner table". Indeed, for numerous TV viewers, "relationships with TV characters [...] are a constant, large, and important part of their social world" [Cohen, 2003]. The television industry is well aware of this phenomenon and makes great efforts to "create, strengthen, and perpetuate such [parasocial] relationships" in order to keep viewers loyal and maximize TV show ratings and revenues [Cohen, 2004].

Furthermore, communication scholars have documented that not only do parasocial relationships share commonalities with real social relationships in terms of their formation, but they also do so when it comes to their dissolution. Several empirical studies have provided evidence that the termination of parasocial relationships is indeed emotionally painful. Cohen [2004] finds that viewers who learn they may hypothetically "lose their favorite [TV] characters anticipate negative reactions similar to those experienced after the dissolution of social relationships". Lather and Moyer-Guse [2011] analyze the emotional reactions experienced by a sample of TV viewers in response to the 2007-2008 Writers Guild of America strike, as a result of which multiple TV series went off the air for a few months. Their findings suggest that the amount of emotional distress produced by a parasocial breakup is positively correlated to the intensity of the original parasocial 
relationship, and even temporary parasocial breakups can generate negative emotional reactions in TV viewers. Eyal and Cohen [2006] and Todd [2011] investigate the public's emotional response to the final episode of the popular sitcom Friends, which attracted 52 million U.S. viewers. They both claim that the conclusion of a popular and beloved TV series is perceived as an emotionally meaningful event, and viewers tend to experience first-hand the sadness that their favorite TV characters typically convey on screen on the occasion of the show's finale. Russell and Schau [2014] analyze the emotional responses of several groups of people to the end of four popular TV series and find that viewers tend to feel sad and a bit lost because they experience a dual loss: the loss of narrative evolution and characters (i.e. the story comes to an end) and the collapse of the social network they built around the series (group viewing/discussion is common among fans of a TV show, and once the show ends the group tends to dissolve).

The fact that a TV series finale can generate "collective mourning among its fans" should not be surprising, considering that "series finales have become media events: they are rituals of farewell that are accompanied by much fanfare and related programming” [Todd, 2011]. Morreale [2000] argues that the media excitement surrounding the last episode of the popular sitcom Seinfeld, which was watched by 76 million U.S. viewers, had a major role in turning it "into a cultural spectacle", "a unifying national moment”. Newspaper articles covering impending finales, promotional spots, and broadcast news stories all contribute to generate the perception that TV show finales are events "to be experienced and remembered", and that they represent "the end of an era in the lives of fans" [Todd, 2011].

Partly as a result of these factors, the public's level of attention around series finales is much higher than around regular episodes of the corresponding TV series. To provide some direct evidence in support of this claim, in Figure 1 I plot the level of Internet search activity drawn over time by a sample of the TV series covered in this study. More specifically, following an event-study 
approach, Figure 1 displays the level of TV series-related weekly Google search activity that is generated in the U.S. in the four-year period that surrounds the typical TV series finale, where week $t$ represents the week in which the finale is broadcast. ${ }^{2}$ The pattern clearly shows that in the week in which the final episode of the typical TV series is aired, not only is the volume of web search queries for the TV series' title abnormally high (almost five standard deviations above the mean), but it is also much higher than at any point in time during the regular run of the series and the postfinale era. This suggests that TV show finales are special events to which the public pays close attention.

Based on the evidence presented in this section, I therefore hypothesize that the end of popular TV series is an emotionally painful event that may generate a wave of negative mood across the population and therefore affect investor sentiment. I also conjecture that the finales that attract more viewers are likely to have a more sizable impact on the aggregate demand for risky assets and asset prices, given that they affect larger portions of the population.

\section{Incidental Mood and Demand for Risky Assets}

Over the past three decades, both psychologists and behavioral finance scholars have documented the existence of a relationship between incidental mood and decision making under risk [Loewenstein et al., 2001]. Mood seems capable of affecting individuals’ risk tolerance, risk perception, and expectations, in turn influencing their choices. Adding complexity to this area of investigation is the fact that conflicting theories have been proposed concerning how mood is expected to sway people's choices, and conflicting empirical results have emerged. In a review of

\footnotetext{
${ }^{2}$ The sample of TV series finales that underlies Figure 1 contains the finales that aired between January 2006 and July 2010. See section 3 for more information about the data employed in this study. The Google search engine had a $64.2 \%$ share of the U.S. Internet search market in July 2010, up from 49.2\% in July 2006 (see http://www.nielsenonline.com/). This suggests that Google search activity is a reasonable proxy for U.S. Internet search behavior.
} 
the literature, Andrade [2005] sorts these theories into two classes, one of which contains the socalled "static affect evaluation theories" and the other the "dynamic affect regulation theories". 3

The static set of theories posits that people's current emotional states can bias their information "processing, judgment, and eventually behavior" either directly or indirectly. Among the direct effects, the affect-as-information model proposed by Schwarz and Clore [1988] claims that, when making a decision, instead of relying on intricate and abstract mental computations, individuals tend to ask themselves: "How do I feel about it?". As a consequence, pre-existing emotional states influence assessments of the problem at hand and choices in a congruent fashion (i.e. incidental bad mood leads to a more negative appraisal of the environment, reducing the propensity to take risk). Bower [1981]'s affect-priming theory, instead, emphasizes the indirect role played by mood. According to this account, non-neutral affective states facilitate the recall of mood-congruent memories, so that individuals in a negative mood are more likely to recall negative things about the situation at hand. In turn, their assessments tend to be more pessimistic because they are based on more negative memories, and they are more likely to opt for safe choices. A third line of research suggests that individuals experiencing positive affect are more likely to make decisions based on simplified, heuristic information processing, whereas individuals in a negative mood tend to engage in analytic, elaborate, and thorough information processing [Bless et al., 1990; Schwarz and Bless, 1991], which makes them more aware of the potential negative outcomes of their choices, increases skepticism, and reduces gullibility [Forgas and East, 2008]. Ultimately, these effects are believed to work in the direction of reducing people's willingness to select risky options. Consistent with these arguments, Johnson and Tversky [1983] and Constans and Matthews

\footnotetext{
${ }^{3}$ Extensive reviews of these two competing streams of literature can also be found in Grable and Roszkowski [2008], Chou et al. [2007], Kim and Kanfer [2009], and Drichoutis and Nayga [2013].
} 
[1993] find that people experiencing a negative mood are more pessimistic, overestimate the probability of negative events and underestimate the likelihood of positive events. Au et al. [2003], using a simulated foreign exchange trading platform, find that traders in a bad mood behave more conservatively by taking small risks. In the field, Edmans et al. [2007] document that national teams' losses in major international sports competitions (a proxy for domestic investor mood) are immediately followed by a drop in domestic stock returns, suggesting that negative mood reduces individuals' demand for risky assets. This result is also confirmed at the firm level by Chang et al. [2012], who observe that firms headquartered near NFL teams experience lowered stock returns after a game loss by the corresponding local team.

Based on this literature and the evidence discussed in the previous section, I therefore formulate the following hypothesis about the impact of TV series finales on stock returns:

\section{$H_{1 a}:$ The wave of negative mood caused by the end of a popular and beloved TV series reduces the net demand for risky assets and decreases stock returns.}

A prerequisite for a TV series finale to influence the aggregate demand for risky assets and asset prices is that such an event must affect a large portion of the population. Series finales that go unnoticed by the general public are unlikely to generate any sizable wave of negative mood across U.S. investors, and in turn they should not be expected to influence U.S. stock returns.

In contrast to the static affect evaluation theories, the dynamic affect regulation theories predict that negative mood will lead to higher asset returns. The mood-maintenance or mood-repair hypothesis [Clark and Isen 1982; Isen and Patrick, 1983] and the mood-management theory [Zillmann, 1988] argue that individuals who are currently experiencing a negative mood will strategically favor high reward/high risk choices in an attempt to dynamically improve (i.e. repair) their affective state. In line with this conjecture, Raghunathan and Pham [1999] find that incidental sadness promotes risk-seeking in hypothetical gambling tasks when individuals bet for themselves 
(i.e. the outcome can have a direct effect on their own mood), whereas it has no discernible influence when they bet on behalf of somebody else. Similarly, Bruyneel et al. [2009] document that negative mood increases people's willingness to purchase lottery tickets. Chuang and Kung [2005] and Lin et al. [2007] document that lab subjects in a sad mood are more inclined to take risks in a series of everyday scenarios, and Leith and Baumeister [1996] find that, in a hypothetical lottery context, emotional distress can be associated with more self-defeating, risk-taking, behavior. More recently, using short film clips to manipulate their lab subjects' moods, Conte et al. [2013] observe that sadness, anger, and fear promote risk-seeking behavior in a series of gambling tasks. Based on the predictions of this stream of literature, I therefore propose a competing hypothesis concerning the impact of TV series finales on stock returns:

$H_{1 b}$ : The wave of negative mood caused by the end of a popular and beloved TV series raises the net demand for risky assets and increases stock returns.

\section{Data}

I collected the main sample of TV series finales employed in this study from a Wikipedia web page that lists the 165 most watched TV series finales in U.S. history based on data aggregated from such sources as Variety, Nielsen Media Research, and USA Today. ${ }^{4}$ For each TV series finale, information was available on the corresponding broadcast date, TV network, estimated number of U.S. viewers, rating, and audience share. Given that these viewership data come from a tertiary source, their accuracy may be suspicious. For this reason, I also constructed a second dataset by hand-collecting data from an array of alternative sources. More precisely, by inspecting historical archives of such secondary sources as newspapers and magazines, I was able to find rating (share) data for $90 \%(86.8 \%)$ of the series finales in the sample. These data are listed in table A.1 in online

\footnotetext{
${ }^{4}$ See http://en.wikipedia.org/wiki/List_of_most_watched_television_broadcasts\#Most_watched_TV_series_finales. I collected the data on August 31, 2012.
} 
Appendix A together with the corresponding data from the tertiary source, revealing that the main dataset is extremely accurate. ${ }^{5}$ For this reason, I conduct the main empirical analysis using the Wikipedia dataset, while I employ the (smaller) alternative dataset in section 4.4 to confirm that the results are robust to the data source.

To validate the main dataset, I also cross-checked each finale's broadcast date with records obtained from the web sites www.tv.com and imdb.com. ${ }^{6}$ The TV series in the sample are mainly sitcoms and dramas. After excluding six unsuitable observations, I ended up with a sample of 159 series finales. ${ }^{7}$ The oldest finale was broadcast on August 29, 1967 (The Fugitive), and the most recent one aired on August 13, 2012 (The Closer). As the traditional TV season runs from September to May, $65.3 \%$ of the finales in the sample aired in May; furthermore, $40.8 \%$ of the finales aired in the weekend. Given that a handful of pairs of finales were broadcast on the same evening or between two nonconsecutive trading days, the final sample contains 147 unique event days (i.e. trading days preceded by a series finale). ${ }^{8}$ Descriptive statistics are reported in Table 1. I collected daily data on the performance of the U.S. stock market from Bloomberg. More specifically, I obtained time series of daily closing values (excluding non-trading days) for the Nasdaq Composite (2/7/1971-8/31/2012), the NYSE Composite (1/4/1967-8/31/2012), the S\&P500 (1/4/1967-8/31/2012), the Russell 3000 (9/10/1987-8/31/2012), and the Russell 2000 indices (9/10/1987-8/31/2012). I employ several indices to make sure that my analysis covers multiple markets, time spans, and categories of stocks. For example, the S\&P500 index focuses on the large cap segment of the market and "includes 500 leading companies in leading industries of the U.S.

\footnotetext{
${ }^{5}$ The average absolute deviation between the two datasets is $0.12 \%$ for ratings and $0.29 \%$ for audience shares.

${ }^{6}$ For a handful of finales the airing date reported in the Wikipedia dataset differed from the one retrieved from $t v . c o m$ and imdb.com. When this happened, I used the latter as the finale date.

${ }^{7}$ I excluded two series that aired on Disney Channel (Hannah Montana, Wizards of Waverly Place) and two series that aired on Nickelodeon (Drake and Josh, Avatar: The Last Airbender), as they mainly targeted teenagers. I also excluded Monday Night Football, a sports television series, and a Miami Vice original episode that was broadcast after the official series finale.

${ }^{8}$ When more than one finale is broadcast on the same day or between two nonconsecutive trading days, I compute the total number of finale viewers by summing up the viewers of the relevant finales. I follow the same approach when calculating TV ratings and audience shares. A handful of rating and share figures were missing.
} 
economy". ${ }^{9}$ The Russell 2000 index, instead, focuses on the small cap segment of the U.S. market, while the Russell 3000 index "measures the performance of the largest 3000 U.S. companies representing approximately $98 \%$ of the investable U.S. equity market". ${ }^{10}$ Some descriptive statistics are displayed in Table 2.

I gathered historical release dates of the macroeconomic indicators featured in Gerlach [2007] - and employed in my empirical analysis - from the Federal Reserve Bank of St. Louis ALFRED database, from the Federal Reserve Bank of Minneapolis’ Beige Book archive, and from the Federal Reserve Board's website. I constructed the time series of the U.S. Treasury term premium (i.e. the spread between the annualized ten-year Treasury note yield and the annualized three-month Treasury bill yield) for the period 1/4/1967-8/31/2012 using data from Bloomberg, whereas I obtained the junk bond premium (1/2/1986-6/29/2012) from the Center for Research in Security Prices (CRSP). Lastly, I collected lunar phase data from the NASA eclipse web site and data about average temperature, wind speed, and rainfall in New York City from the National Climatic Data Center in Asheville (NC). ${ }^{11}$

\section{Empirical Analysis}

\subsection{Baseline Model}

To test the hypotheses introduced in section 2, I follow several steps. The first phase consists in employing a simple OLS regression model in which the dependent variable measures daily returns to a broad index of the U.S. stock market:

$$
\begin{aligned}
r_{t}= & \alpha+\beta_{1} \text { FINALE }_{t-1}+\beta_{2} \text { FINALE }_{t-1} \times \ln \left(\text { VIEWERS }_{t-1}\right)+\gamma_{1} \text { PRE }_{t}+\gamma_{2} \text { POST }_{t}+ \\
& +\sum_{n=1}^{4} \delta_{n} D W_{n t}+\sum_{k=1}^{11} \eta_{k} D M_{k t}+\varepsilon_{t}
\end{aligned}
$$

\footnotetext{
${ }^{9} \mathrm{http}$ ///www.standardandpoors.com/indices/sp-500/en/us/?indexId=spusa-500-usduf--p-us-1--.

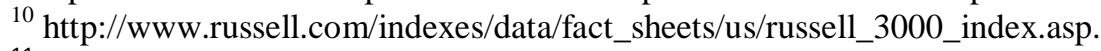

${ }^{11}$ http://eclipse.gsfc.nasa.gov/phase/phasecat.html.
} 
where

$r_{t}=$ the realized continuously compounded (close-to-close) return to a given U.S. stock market index from trading day $t-1$ to $t$,

$F I N A L E_{t-1}=$ a dummy variable that takes value 1 if a TV series finale is broadcast between the market closing on trading day $t-1$ and the market opening on trading day $t$ and 0 otherwise, ${ }^{12}$

$V I E W E R S_{t-1}=$ the estimated number of U.S. viewers (in millions) watching the series finale that aired between the market closing on trading day $t-1$ and the market opening on trading day $t,{ }^{13}$

$P R E_{t}=$ a dummy variable equal to 1 on trading days that immediately precede a holiday (New Year's Day, President's Day, Good Friday, Memorial Day, Independence Day, Labor Day, Thanksgiving Day, and Christmas Day) and 0 otherwise [see Ariel, 1990], ${ }^{14}$

$\operatorname{POST}_{t}=$ a dummy variable that takes value 1 on trading days that immediately follow a holiday and 0 otherwise [Lakonishok and Smidt, 1988],

$D W_{n t}=$ dummy variables for four of the five weekdays (excluding Wednesday), $D M_{k t}=$ dummy variables for eleven of the twelve calendar months (December is the excluded month).

Regression model (1) contains a set of calendar dummy variables to control for several well-known calendar anomalies [e.g. Jaffe and Westerfield, 1985; Chang and Pinegar, 1989], as TV series finales tend to cluster in May and tend to be followed by a Monday trading day.

\footnotetext{
${ }^{12}$ This implies that a series finale that airs on a Saturday evening is assumed to affect the investment decisions that are implemented the following Monday.

${ }_{13}^{13}$ More precisely, I add the constant 1 to each observation to avoid the possibility of taking the $\log$ of 0 .

${ }^{14}$ Historical holiday dates were collected from the website http://www.timeanddate.com/.
} 
The estimates for each of the five stock market indices are reported in Table 3 (columns 1 through 5). To perform statistical inference I compute Newey-West robust standard errors (with three lags). ${ }^{15}$ The signs and the sizes of the coefficients on the two variables of interest are consistent across the five indices. $\beta_{1}$ is estimated to be positive and statistically significant at the $1 \%$ level for three of the indices (Nasdaq, Russell 3000, Russell 2000). In the remaining two cases the corresponding $p$-values are less than 0.05 , so the null hypothesis of $\beta_{1}=0$ can always be rejected at standard significance levels. $\beta_{2}$ is negative and statistically significant at the $1 \%$ level for three of the indices (Nasdaq, Russell 3000, Russell 2000) and at the 5\% for the remaining two. In most instances, the null hypothesis that the coefficients on the TV series finale dummy and the interaction term are jointly equal to zero can be rejected at the $5 \%$ level of significance (for the NYSE index the $p$-value is 0.052 ). It is worth emphasizing that the coefficient $\beta_{1}$ should not be evaluated on its own, as the dummy FINALE appears both alone and interacted with VIEWERS in model (1). Together with the other coefficients, it reveals that the typical TV series finale - which is watched by 15.52 million viewers, airs in May, and is followed by a Monday trading day - is estimated to be followed by a negative daily stock return $(-0.12 \%)$, all else equal. ${ }^{16}$ The negative sign of the coefficient $\beta_{2}$ suggests that an increase in the size of the TV audience for a given series finale is estimated to lower stock returns on the next trading day, all else equal. More in detail, a $20 \%$ increase in the number of viewers is estimated to be followed by approximately an 8 basis point reduction is equity returns. ${ }^{17}$ If a quite popular series finale airs on day $t$, and the number of viewers is one standard deviation (15.55 million viewers) above the sample average, then stock

\footnotetext{
${ }^{15}$ The results are robust to the choice of the lag structure.

${ }^{16}$ For the Nasdaq index, holding all other variables constant at zero, $\left.E(r)\right|_{\text {FINALE }=1, \text { VIEWERS }=15.52, D W_{1}=1, D M_{5}=1}=-0.12$.

${ }^{17}$ The effect is not exactly constant, though. It can be readily seen that the exact magnitude of this effect depends on where the baseline number of viewers is. Taking the average number of viewers as a baseline, and holding all other regressors constant (with FINALE $=1$ ), a $20 \%$ increase in audience size is estimated to have the following impact on next-day returns:

$$
\left.E(r)\right|_{\text {VIEWERS }_{2}}-\left.E(r)\right|_{\text {VIEWERS }}=\beta_{2} \times \ln \left(\frac{1+\mathrm{VIEWERS}_{2}}{1+\mathrm{VIEWERS}_{1}}\right)=\beta_{2} \times \ln \left(\frac{1+15.52 \times 1.20}{1+15.52}\right)=-0.08 .
$$
}


returns are estimated to fall by approximately 25 basis points on day $t+1$, all else constant. In other words, the greater the popularity of a TV series, the larger the decrease in stock returns following the finale. Similar patterns emerge when considering the other market indices. This initial result is therefore consistent with the conjecture that the end of popular TV series, by generating a wave of negative mood across the population, decreases the demand for risky assets and, in turn, reduces equity returns. Furthermore, the table reveals that the point estimate of this effect is largest for the Russell 2000 index and smallest for the NYSE and S\&P500 indices; this pattern is precisely consistent with a mood interpretation of the results, given that small cap stocks play a larger role in the former index, and individual investors have a stronger impact on the pricing of small stocks [Sias and Starks, 1997] and are more likely to be affected by sentiment [Kumar and Lee, 2006].

As for the remaining variables, the coefficient on the pre-holiday dummy is estimated to be positive in all five indices, and statistical significance is achieved in the case of the Nasdaq, NYSE, and S\&P500 indices. For these three indices, returns on pre-holiday trading days are estimated to be approximately 15 basis points higher than on regular days, confirming the findings of Lakonishok and Smidt [1988] and Ariel [1990]. The sign of the coefficient on the post-holiday dummy, on the other hand, does not seem to follow any uniform pattern, and the coefficient itself is extremely small and never statistically different from zero. Confirming earlier findings, when the day-of-theweek effect is analyzed, there seems to be substantial evidence that mean returns are lower on Mondays, as the coefficient on the Monday dummy is negative and statistically significant at the $1 \%$ level (except for the Russell 3000 index). The magnitude of this coefficient varies between 7 basis points (Russell 3000) and 23 basis points (Nasdaq). In terms of monthly patterns, September is the only month whose coefficient is statistically different from zero across the five indices. More specifically, mean returns are lower in this month, and the effect ranges from 11 basis points (NYSE) to 17 basis points (Russell 2000). The coefficient on the May dummy, too, is negative and 
approaches statistical significance in two instances (NYSE and S\&P500). Lastly, when considering all regressors at once, the Russell 3000 is the only index for which the hypothesis that the coefficients on all explanatory variables are equal to zero cannot be rejected at standard levels of significance.

\subsection{Controlling for Economic News}

Regression model (1) does not contain any standard economic variables, so it is natural to wonder whether the effect documented in the previous section stems from the fact that some series finales happen to air on the same days when some relevant economic news hits the market. In this regard, Gerlach [2007] argues that (at least) some of the (weather-induced) mood effects that have been presented in the behavioral finance literature are in fact simply the result of the market rational response to macroeconomic news. He finds that mean returns on days in which key macroeconomic announcements are made are statistically significantly different from returns on non-announcement days, and the alleged mood effects are not present at all on trading days in which no announcement is made.

To address these concerns, I employ two approaches. First, following Flannery and Protopapadakis [2002], I augment model (1) with a set of three financial variables that previous research has found to affect conditional mean returns. Second, in the spirit of Gerlach [2007], I include a set of eleven dummy variables to control for the announcement dates of eleven major macroeconomic series. The resulting model takes the following form:

$$
\begin{aligned}
r_{t}= & \alpha+\beta_{1} \text { FINALE }_{t-1}+\beta_{2} \text { FINALE }_{t-1} \times \ln \left(\text { VIEWERS }_{t-1}\right)+\omega_{1} r_{t-1}+\omega_{2} \text { TPRE }_{t-1}+ \\
& +\omega_{3} \text { JPRE }_{t-1}+\sum_{j=1}^{11} \mu_{j} \text { MACRO }_{j t}+\gamma_{1} \text { PRE }_{t}+\gamma_{2} \text { POST }_{t}+\sum_{n=1}^{4} \delta_{n} D W_{n t}+\sum_{k=1}^{11} \eta_{k} D M_{k t}+\varepsilon_{t}
\end{aligned}
$$

where 
$r_{t-1}=$ the one-day lagged stock market index return [e.g. Conrad and Kaul, 1988],

$T P R E_{t-1}=$ the one-day lagged Treasury term structure premium, i.e. the spread between the ten-year U.S. Treasury note yield and the three-month Treasury bill yield [e.g. Fama and French, 1989; Schwert, 1990],

$J P R E_{t-1}=$ the one-day lagged junk bond premium, i.e. the spread between the yields on Moody's Baa and Aaa bonds [see Flannery and Protopapadakis, 2002],

$M A C R O_{j t}=$ eleven dummy variables that take value 1 if a specific macroeconomic announcement (Fed's Beige Book, Inventories, CPI, Employment Situation, Advance Durable Goods Shipments, Federal Open Market Committee (FOMC) statements, GDP, Housing Starts, Industrial Production, Retail Sales, Vehicle Sales) is made on trading day $t$ and 0 otherwise. ${ }^{18}$

The estimates, reported in Table 4, suggest that over the period under investigation stock prices reacted positively to the release of FOMC statements. The coefficient on the FOMC announcement dummy is positive and statistically significant at the $1 \%$ level across the five indices. On trading days in which the FOMC releases a statement, U.S. equity returns are estimated to increase by 43 61 basis points, all else equal, depending on the market index. Conversely, the coefficient on the Inventories announcement dummy is negative and approaching significance $(p$-value $=0.068)$ in the case of the Nasdaq index, but the null hypothesis of its equality to zero cannot be rejected for the other indices. All the coefficients on the remaining macroeconomic dummies are always statistically indistinguishable from zero, as are the coefficients on the Treasury term spread and the

\footnotetext{
${ }^{18}$ This is exactly the same set of announcements used by Gerlach [2007], who originally focused on them as they are considered as the most relevant by the Federal Reserve. The time series of macro announcements that I employ cover various time spans, the longest being for CPI, Employment Situation, GDP, Industrial Production, and Retail Sales (Jan 1967 - Aug 2012), and the shortest being for Vehicle Sales (Mar 1997 - Aug 2012).
} 
junk bond premium. ${ }^{19}$ One-day lagged returns have a negative and statistically significant coefficient $(p$-value $=0.029)$ in the case of the S\&P500 index, whereas insignificant results are obtained for the other indices.

Despite the new additions, $\beta_{1}$ and $\beta_{2}$ are still statistically significant, both individually and jointly, across the five market indices. Moreover, their signs and magnitudes are fully consistent with the estimates from model (1). I obtained analogous results when, instead of using dummy variables to capture the effects of major macroeconomic announcements, I dropped from the sample all trading days in which at least one announcement occurred. Though the list of economic news releases employed here is not exhaustive, these outcomes suggest that the correlation between TV series finales and equity returns is unlikely to be explained by investors' response to market-wide economic news.

\subsection{Controlling for Alternative Mood Proxies}

As previously discussed, several investor mood proxies have already been employed in the empirical behavioral finance literature. Most researchers have focused on some environmental factors that are believed to trigger mood reactions in large portions of the population, or at least in the group of institutional agents (e.g. market makers) who are physically located in the city that hosts a given stock exchange [Goetzmann and Zhu, 2005]. At the same time, some communication scholars argue that media consumption choices are at least partly inspired by mood (see e.g. Zillmann [1988]'s mood-management theory). Thus, one may wonder whether some environmental mood triggers can affect both stock returns and TV viewing choices, in turn being responsible for the TV show finale effect discussed here. For example, seasonal depression may reduce stock prices [Kamstra et al., 2003] and at the same time prompt people to spend more time watching sitcoms on

\footnotetext{
${ }^{19}$ Since the coefficient on the junk bond premium is statistically insignificant, and the junk bond premium data in my possession only cover a fraction of the period under investigation (from January 1986 through June 2012), in the regressions that follow I drop this variable. The results are qualitatively similar if the variable is kept in the model.
} 
TV to self-regulate their mood. To address these concerns, I augment model (2) with a set of frequently employed environmental variables, as follows:

$$
\begin{aligned}
r_{t} & =\alpha+\beta_{1} \text { FINALE }_{t-1}+\beta_{2} \text { FINALE }_{t-1} \times \ln \left(\text { VIEWERS }_{t-1}\right)+\lambda_{1} \text { FALL }_{t}+\lambda_{2} \text { SAD }_{t}+ \\
& +\lambda_{3} \text { NEWMOON }_{t}+\lambda_{4} \text { FULLMOON }_{t}+\lambda_{5} \text { TEMP }_{t}+\lambda_{6} \text { WIND }_{t}+\lambda_{7} \text { RAIN }_{t}+\omega_{1} r_{t-1}+ \\
& +\omega_{2} \text { TPRE }_{t-1}+\sum_{j=1}^{11} \mu_{j} \text { MACRO }_{j t}+\gamma_{1} \text { PRE }_{t}+\gamma_{2} \text { POST }_{t}+\sum_{n=1}^{4} \delta_{n} D W_{n t}+\sum_{k=1}^{11} \eta_{k} D M_{k t}+\varepsilon_{t}
\end{aligned}
$$

where

$F A L L_{t}=$ a dummy variable equal to 1 in the fall season and 0 otherwise,

$S A D_{t}=$ a variable, constructed as in Kamstra et al. [2003], that measures the standardized number of hours of night in New York City on day $t$ and, together with $F A L L_{t}$, is employed to control for the seasonal affective disorder effect,

$N E W M O O N_{t}=$ a dummy variable that takes value 1 from calendar day $t$ - 3 through calendar day $t+3$ (where $t$ is a calendar day in which a new moon occurs) and 0 otherwise [Yuan et al., 2006],

FULLMOON $_{t}=$ a dummy variable that takes value 1 from calendar day $t$ - 3 through calendar day $t+3$ (where $t$ is a calendar day in which a full moon occurs) and 0 otherwise,

$T E M P_{t}=$ a variable that measures the average temperature $\left({ }^{\circ} \mathrm{F}\right)$ in New York City on trading day $t$ [Cao and Wei, 2005],

$W I N D_{t}=$ a variable that measures the average wind speed (knots) in New York City on trading day $t$ [Keef and Roush, 2005],

$\operatorname{RAIN}_{t}=$ a zero-one dummy variable that indicates a null or positive amount of rainfall in New York City on trading day $t$, respectively [Dowling and Lucey, 2005]. 
The results are reported in Table 5. Individually, the coefficient on the RAIN dummy is negative and statistically significant at conventional levels in three instances (Nasdaq, S\&P500, and Russell 2000). This pattern is in line with previous findings. A rainy day, allegedly through its negative impact on mood, is estimated to reduce stock returns by $4-8$ basis points, depending on the index, all else equal. Contrary to Keef and Roush [2005]'s findings, the coefficient on WIND is estimated to be positive, but statistical significance at the 5\% level is achieved in only two instances (NYSE and S\&P500). The coefficient on FALL is negative and highly statistically significant for most of the five market indices, in line with previous findings. The coefficient on $S A D$ is estimated to be positive, as in Kamstra et al. [2003], yet statistical significance is achieved only in the case of the Russell 2000 index. For the remaining environmental variables the null hypothesis of no linear relationship with U.S. equity returns cannot be rejected at standard levels of significance.

Including this set of investor mood proxies does not affect the patterns concerning $\beta_{1}$ and $\beta_{2}$, which maintain the same signs and (individual and joint) statistical significance as in models (1) and (2). Virtually identical outcomes are obtained if some lags of the same environmental variables are added to model (3). The magnitudes of $\beta_{1}$ and $\beta_{2}$ are also consistent with the previous results, which suggests that the relationships among TV series finales, finale viewership patterns, and U.S. equity returns cannot be attributed to previously detected mood variables.

\subsection{Alternative TV Viewership Measures}

In models (1) through (3) I proxied for the popularity of TV series and their finales with the corresponding estimated number of U.S. viewers. In order to verify that the results are robust to the choice of the popularity measure, here I re-estimate model (3) using two alternative quantities. First, I replace the number of viewers with the corresponding TV series finale's rating (i.e. the percentage 
of U.S. households with a TV set that were tuned to the TV series finale).$^{20}$ The estimates, reported in Table 6 (column a), reveal that $\beta_{1}$ and $\beta_{2}$ have the same signs as in the previous models and are statistically significant (both individually and jointly) at least at the 5\% level across all five market indices. Considering the Nasdaq index, for example, if a quite popular TV series finale airs on day $t$, and the finale's rating is one standard deviation (9.48\%) above the average event's rating (10.14\%), then stock returns are estimated to fall by approximately 26 basis points on day $t+1$, all else constant. Similar results emerge when referring to the other market indices. The magnitude of this effect is very much in line with the findings reported in the previous section, and its sign is once again consistent with the hypothesis that the end of popular TV series has a negative impact on the demand for risky assets by spurring a wave of negative mood across the population. As a second robustness exercise, I replace the number of viewers with the TV series finale's share (i.e. the percentage of U.S. households actually using a TV set that were tuned to the TV series finale). The estimates that I obtain are virtually identical to the ones found in the previous step and, therefore, I do not report them here.

As anticipated in section 3, it may be natural to wonder if the TV viewership data employed so far are trustworthy, as I obtained them from a tertiary source. To address this concern, I repeat the last two steps of my analysis using an alternative dataset consisting of TV rating and share data that I hand-collected from reliable secondary sources (see Appendix A). The results that I obtain when using TV ratings as the explanatory variable of interest in equation (3) are displayed in Table 6 (column b). They confirm the findings reported earlier, as the signs, sizes, and statistical significance of $\beta_{1}$ and $\beta_{2}$ (individually and jointly) conform very well to the patterns generated when using the main dataset (column a). Analogously, I obtain very similar results (not reported

\footnotetext{
${ }^{20}$ I add the constant 1 to each observation to avoid the possibility of taking the log of 0 . For six series finales the rating data were missing.
} 
here) when using audience shares as the relevant explanatory variable. Therefore, the findings presented here are robust to the choice of the data source.

Online Appendix B contains some additional analyses that reveal that the results are stable across time and are unlikely to be caused by outliers, changes in market liquidity, heteroschedasticity in the error term of the regression equation, or the subject matter (e.g. happy, sad) of the TV series in the sample.

\subsection{Cross-sectional Evidence}

In this section, I investigate whether the TV show finale effect differs across stocks using as a dependent variable in model (3) daily returns to portfolios of stocks sorted by size, volatility, and industry. ${ }^{21}$ In terms of size, there is evidence that small stocks tend to be disproportionally held by individual investors [Sias and Starks, 1997], whose decisions are supposed to be more sensitive to mood variations than is the case for institutional investors. Additionally, small stocks are riskier to arbitrage than large stocks, as they are more costly to trade [Amihud and Mendelson, 1986] and expensive to sell short [Jones and Lamont, 2002]. Similarly, high-volatility stocks are riskier to arbitrage than low-volatility ones [Baker and Wurgler, 2007], and investor mood is believed to exert a larger influence on the pricing of stocks that are difficult to arbitrage [Baker and Wurgler, 2006; Kumar, 2009].

Based on these insights, if mood is responsible for the empirical patterns documented in this study, one would expect small stocks and highly volatile stocks to exhibit a stronger TV series finale effect. When I analyze the returns to the portfolios, the estimated signs of $\beta_{1}$ and $\beta_{2}$ are indeed in line with this conjecture and the findings reported earlier. Due to space constraints, here I only display $\beta_{2}$ 's point estimates in graphical form. Figure 2 reveals that, with the exception of the

\footnotetext{
${ }^{21}$ More specifically, I use the returns to the Fama and French [1992] ten value-weighted portfolios constructed by size and industry (from Kenneth French's data library) and CRSP returns computed on standard deviation-based deciles. The samples cover the period 1/3/1967-12/30/2011.
} 
smallest size decile, $\beta_{2}$ is estimated to nearly monotonically decrease (in absolute value) with size ${ }^{22}$. This suggests that a given increase in the popularity (number of viewers) of a TV show finale is estimated to have a larger impact on the pricing of smaller stocks, which are exactly the ones that are more sensitive to investor mood. Statistical inference also reveals that $\beta_{1}$ and $\beta_{2}$ are jointly statistically significant at conventional levels for all size decile portfolios. As for the volatilitybased portfolios, a very similar nearly monotonic relationship appears in Figure $3 .{ }^{23}$ With the exception of the highest volatility decile, as the portfolio volatility increases, $\beta_{2}$ is estimated to increase (in absolute value), which again confirms that the TV series finale effect is stronger for stocks whose pricing is more sensitive to investor mood. Lastly, moving the focus to the industry portfolios, Figure 4 reveals that the effect documented in this study is pervasive and is unlikely to be driven by industry-specific news (e.g. shocks to the entertainment industry), as $\beta_{2}$ is negative and statistically significant (individually and jointly with $\beta_{1}$ ) for the majority of the industries considered. $^{24}$

\section{Concluding Remarks}

The use of the discrete mood variable employed in this study - the end of popular TV series finds strong a priori motivation in the psychology and communication literature. The last episode of long-running and highly rated TV shows seems to "mark a farewell of some import to many millions" of viewers [Eyal and Cohen, 2006] and, similarly to real social breakups, is perceived as an emotionally painful event. Given the pervasiveness of television consumption in the U.S., I

\footnotetext{
${ }^{22}$ Yuan et al. [2006] argue that "[1]iquidity and market microstructure related issues are likely to have a first-order effect in pricing extreme small stocks rather than mood". Kendall's tau rank correlation coefficient confirms that the link between stock size and $\beta_{2}$ is highly statistically significant ( $p$-value $=0.005$ ) if the smallest size decile is excluded. If the smallest size decile is included, the $p$-value is 0.107 .

${ }^{23}$ Kendall's tau rank correlation coefficient confirms that the link between portfolio volatility and $\beta_{2}$ is highly statistically significant $(p$-value $=0.001)$.

${ }^{24}$ The Other portfolio contains firms that operate in the following industries: building materials, business services, construction, entertainment, finance, hotels, mines, and transportation.
} 
conjecture that there exists a considerable overlap between TV viewers and stock market investors. In this context, the use of a discrete (zero-one) mood variable built upon TV show finales facilitates isolating abrupt shifts in investor mood, which generates a favorable signal-to-noise ratio in stock market returns [Edmans et al., 2007]. Consistently with the static affect evaluation theories that claim that negative mood promotes pessimistic expectations and risk aversion, I find that major TV series finales that attract large numbers of U.S. viewers are immediately followed by a decline in U.S. stock returns, which suggests that negative mood reduces the net demand for risky assets.

It is natural to wonder why these results run counter to the predictions of the dynamic affect regulation theories and, more in general, why the two streams of literature discussed in section 2 offer conflicting predictions and empirical evidence. I can advance several explanations in this regard. Some authors have attempted an integrative approach and have suggested that the two groups of theories are built upon complementary rather than competing mechanisms, so that which effect prevails depends on the features of the task, e.g. whether the activity at hand can play a role in regulating the individual's current affective state [Andrade, 2005; Gendolla, 2000]. A second possibility is that the amount of time and the activities that intervene between the mood induction and the decisions being made play a relevant role. For example, Kim and Kanfer [2009] show that if, after being administered a negative mood induction procedure, participants perform an activity that helps them repair their mood (e.g. a cognitively demanding task), then they display lower risktaking preferences in a subsequent risk judgment task than participants who were not allowed to engage in said activity. In the context of the present study, on may speculate that real-world investors are likely to perform several mood-lifting (e.g. cognitive) daily life activities after watching a TV series finale and before implementing their next-day investment decisions, which may explain why their financial choices do not appear to be guided by an affect regulation objective. Lastly, while lab subjects typically have only one way to improve their moods within the 
time span of the experiment (i.e. by choosing the high reward/high risk gambles), real-world investors suffering from negative mood can opt to repair their affect by e.g. choosing consumption over investment. ${ }^{25}$ The stream of research on so-called "retail therapy" indeed claims that bad mood leads to increased consumption for mood-regulation purposes [e.g. Atalay and Meloy, 2011], which suggests that the decline in the demand for risky assets following negative mood-inducing events might be the result of an emotional choice to consume more and invest less. This argument bears practical implications for future research. More specifically, future lab experiments could shed some light on this mechanism by allowing participants in a non-neutral mood to choose among high risk/high reward gambles, low risk/low reward gambles, and current consumption.

As a final note, though the analysis presented here sheds light on the role that investor mood plays in asset pricing, the future applicability of the findings should be evaluated in the context of changing television technology and viewers' consumption habits. The proliferation of cable networks in the 1990s and the arrival of new broadcast networks have progressively enlarged the range of choice available to viewers and led to an increased audience fragmentation [Webster et al., 2013]. Similarly, new technologies such as video cassette recorders, DVDs, personal video recorders (such as TiVo), and Internet downloading of video have gradually altered TV watching practices, allowing viewers to record TV content that is watched at a future time of their choice [Barkhuus and Brown, 2009]. These changes imply that fewer and fewer TV series finales might be able to attract the attention of a large fraction of the population at exactly the same time, which in turn might reduce the frequency with which aggregate investor mood will be affected by said events.

\footnotetext{
${ }^{25}$ I thank an anonymous reviewer for suggesting this mechanism.
} 


\section{Appendix A}

See Table A.1. (link to online Appendix)

\section{Appendix B - Supplementary material} http://..

Supplementary information associated with this article can be found, in the online version, at 


\section{References}

Amihud Y. and H. Mendelson (1986). Asset Pricing and the Bid-Ask Spread, Journal of Financial Economics, 17, pp. 223-249.

Andrade E. B. (2005). Behavioral consequences of affect: Combining evaluative and regulatory mechanisms, Journal of Consumer Research, 32, pp. 355-362.

Ariel R. (1990). High Stock Returns before Holidays: Existence and Evidence on Possible Causes, Journal of Finance, 45(5), pp. 1611-1626.

Atalay A. S. and M. G. Meloy (2011). Retail Therapy: A Strategic Effort to Improve Mood, Psychology \& Marketing, 28(6), pp. 638-660.

Au K., F. Chan, D. Wang and I. Vertinsky (2003). Mood in foreign exchange trading: Cognitive processes and performance, Organizational Behavior and Human Decision Processes, 91, pp. 322-338.

Baker M. and J. Wurgler (2006). Investor sentiment and the cross-section of stock returns, Journal of Finance, 61, pp. 1645-1680.

Baker M. and J. Wurgler (2007). Investor sentiment in the stock market, Journal of Economic Perspectives, 21, pp. 129-151.

Barkhuus L. and B. Brown (2009). Unpacking the Television: User Practices around a Changing Technology, ACM Transactions on Computer-Human Interaction, 16(3), Article 15, 22 pages.

Bless H., G. Bohner, , N. Schwarz, and F. Strack (1990). Mood and persuasion: A cognitive response analysis, Personality and Social Psychology Bulletin, 16(2), pp. 331-345.

Bower G. H. (1981). Mood and memory, American Psychologist, 36, pp. 129-148.

Bruyneel S., S. Dewitte, P. H. Franses, and M. G. Dekimpe (2009). I Felt Low and My Purse Feels Light: Depleting Mood Regulation Attempts Affect Risk Decision Making, Journal of Behavioral Decision Making, 22, pp. 153-170.

Cao M. and J. Wei (2005). Stock Market Returns: a Note on Temperature Anomaly, Journal of Banking and Finance, 29, 1559-1573.

Chang E. C. and J. M. Pinegar (1989). Seasonal Fluctuations in Industrial Production and Stock Market Seasonals, Journal of Financial and Quantitative Analysis, 24(1), pp. 59-74.

Chang S. C., S. S. Chen, R. K. Chou, and Y. H. Lin (2012). Local sports sentiment and returns of locally headquartered stocks: A firm-level analysis, Journal of Empirical Finance, 19(3), pp. 309-318.

Chou K., M. C. Lee, and H. Y. Ho (2007). Does Mood State Change Risk Taking Tendency in Older Adults?, Psychology and Aging, 22(2), pp. 310-318. 
Chuang S. C. and C. Kung (2005). The effects of emotions in risk-taking, Journal of American Academy of Business, 6(2), pp. 113-118.

Chuang W. and B. Lee (2006). An empirical evaluation of the overconfidence hypothesis, Journal of Banking and Finance, 30, pp. 2489-2515.

Clark M. S. and A. M. Isen (1982). Towards understanding the relationship between feeling states and social behavior. In Hastorf A. H., Isen A. M. (Eds.), Cognitive social psychology (pp. 73-108). New York, NY: Elsevier-North Holland.

Cohen J. (2003). Parasocial Breakups: Measuring Individual Differences in Responses to the Dissolution of Parasocial Relationships, Mass Communication and Society, 6(2), pp. 191-202.

Cohen J. (2004). Parasocial break-up from favorite television characters: The role of attachment styles and relationship intensity, Journal of Social and Personal Relationships, 21, pp. 187-202.

Conrad, J. and G. Kaul (1988). Time-Variation in Expected Returns, Journal of Business, 61, pp. 409426.

Constans J. J. and A. M. Mathews (1993). Mood and the subjective risk of future events, Cognition and Emotion, 7(6), pp. 545-560.

Conte A. M. V. Levati, and C. Nardi (2013). The Role of Emotions on Risk Preferences: An Experimental Analysis, Jena Economic Research Papers 2013 - 046.

Dowling M. and B. M. Lucey (2005). Weather, biorhythms, beliefs and stock returns - Some preliminary Irish evidence, International Review of Financial Analysis, 14(3), pp. 337-355.

Drichoutis A. C. and R. M. Nayga Jr. (2013). Eliciting risk and time preferences under induced mood states, Journal of Socio-Economics, 45, pp. 18- 27.

Durmer J. S. and D. F. Dinges (2005). Neurocognitive consequences of sleep deprivation, Seminars in Neurology, 25, pp. 117-129.

Edmans A., D. García, and Ø. Norli (2007). Sports Sentiment and Stock Returns, Journal of Finance, 62, pp. 1967-1998.

Engle-Friedman M., S. Riela, R. Golan, A. M. Ventuneac, C. M. Davis, A. D. Jefferson, and D. Major (2003). The effect of sleep loss on next day effort, Journal of Sleep Research, 12, pp. 113-124.

Eyal K. and J. Cohen (2006). When good Friends say goodbye: A parasocial breakup study, Journal of Broadcasting \& Electronic Media, 50, pp. 502-523.

Fama E. and K. French (1989). Business Conditions and Expected Returns on Stocks and Bonds, Journal of Financial Economics, 25, pp. 23-49.

Fama E. and K. French (1992). The cross-section of expected stock returns, Journal of Finance, 47, pp. 427-467. 
Flannery M. J. and A. A. Protopapadakis (2002). Macroeconomic factors do influence aggregate stock returns, Review of Financial Studies, 15, pp. 751-82.

Forgas J. P. and R. East (2008). On being happy and gullible: Mood effects on scepticism and the detection of deception, Journal of Experimental Social Psychology, 44, pp.1362-1367.

Gendolla G. H. E. (2000). On the impact of mood on behavior: An integrative theory and a review, Review of General Psychology, 4(4), pp. 378-408.

Gerlach J. R. (2007). Macroeconomic news and stock market calendar and weather anomalies, The Journal of Financial Research, 30(2), pp. 283-300.

Goetzmann W. N. and N. Zhu (2005). Rain or shine: where is the weather effect?, European Financial Management, 11(5), pp. 559-578.

Grable J. E. and M. J. Roszkowski (2008). The influence of mood on the willingness to take financial risks, Journal of Risk Research, 11(7), pp. 905-923.

Hirshleifer D. and T. Shumway (2003). Good Day Sunshine: Stock Returns and the Weather, Journal of Finance, 58(3), pp. 1009-1032.

Horton D. and R. R. Wohl (1956). Mass communication and para-social interaction, Psychiatry, 19, pp. 215-229.

Huber P. J. (1967). The behavior of maximum likelihood estimates under non-standard conditions, Proceeding of the Fifth Berkeley Symposium on Mathematical Statistics and Probability, 1, pp. 221233.

Isen A. M. and R. Patrick (1983). The effects of positive feelings on risk-taking: When the chips are down, Organizational Behavior and Human Decision Processes, 31, pp. 194-202.

Jaffe J. and R. Westerfield (1985). The Week-End Effect in Common Stock Returns: The International Evidence, Journal of Finance, 40, pp. 433-454.

Johnson E. J. and A. Tversky (1983). Affect, generalization and the perception of risk, Journal of personality and social psychology, 45, pp. 20-31.

Jones C. and O. Lamont (2002). Short Sales Constraints and Stock Returns, Journal of Financial Economics, 66, pp. 207-39.

Kamstra M., L. A. Kramer, and M. D. Levi (2000). Losing sleep at the market: the daylight-savings anomaly, American Economic Review, 90(4), pp. 1005-1011.

Kamstra M. J., L. A. Kramer, and M. D. Levi (2003). Winter Blues: A SAD Stock Market Cycle, American Economic Review, 93(1), pp. 324-333.

Kaplanski G. and H. Levy (2010). Sentiment and stock prices: The case of aviation disasters, Journal of Financial Economics, 95(2), pp. 174-201. 
Keef S. P. and M. L. Roush (2005). Influence of weather on New Zealand financial securities, Accounting and Finance, 45, pp. 415-437.

Kim M. Y. and R. Kanfer (2009). The joint influence of mood and a cognitively demanding task on risk-taking, Motivation and Emotion, 33, pp. 362-372.

Kleinginna P. R. Jr and A. M. Kleinginna (1981). A categorized list of emotion definitions, with suggestions for a consensual definition, Motivation and emotion, 5(4), pp. 345-379.

Kumar A. (2009). Hard-to-Value Stocks, Behavioral Biases, and Informed Trading, Journal of Financial and Quantitative Analysis, 44(6), pp. 1375-1401.

Kumar A. and C. M. C. Lee (2006), Retail Investor Sentiment and Return Comovements, Journal of Finance, 61, pp. 2451-2486.

Lakonishok J. and S. Smidt (1988). Are seasonal anomalies real? A ninety-year perspective, Review of Financial Studies, 1(4), pp. 403-425.

Lather J. and E. Moyer-Guse (2011). How Do We React When Our Favorite Characters Are Taken Away? An Examination of a Temporary Parasocial Breakup, Mass Communication and Society, 14(2), pp. 196-215.

Leith K. P. and R. F. Baumeister (1996). Why do bad moods increase self-defeating behavior? Emotion, risk taking and self-regulation, Journal of Personality and Social Psychology, 71, pp. 1250-1267.

Lin C. H., H. R. Yen, and S.-C. Chuang (2007). The effects of emotion and need for cognition on consumer choice involving risk, Journal of Business and Psychology, 22(1), pp. 65-78.

Loewenstein G., E. U. Weber, C. K. Hsee, and N. Welch (2001). Risk as feelings, Psychological Bulletin, 127, pp. 267-286.

Lucey B. and M. Dowling (2005). The role of feelings in investor decision-making, Journal of Economic Surveys, 19, pp. 211-237.

Mills N. (1998). So long, Jerry Seinfeld, Dissent Magazine, Summer 1998 issue.

Mohebbi M., D. Vanderkam, J. Kodysh, R. Schonberger, H. Choi, and S. Kumar (2011). Google correlate whitepaper, available at www.google.com/trends/correlate/whitepaper.pdf.

Morreale J. (2000). 'Sitcoms Say Good-Bye: The Cultural Spectacle of Seinfeld's Last Episode. Critiquing the Sitcom: A Reader. Ed. J. Morreale. Syracuse: Syracuse UP, pp. $274-85$.

National Sleep Foundation (2003). 2003 Sleep in America Poll. Washington (DC): The Foundation. Available from: http://sleepfoundation.org/sleep-polls-data/sleep-in-america-poll/2003-sleep-and-aging.

National Sleep Foundation (2010). 2010 Sleep in America Poll. Washington (DC): The Foundation. Available from: http://sleepfoundation.org/sleep-polls-data/sleep-in-america-poll/2010-sleep-andethnicity. 
National Sleep Foundation (2011). 2011 Sleep in America Poll. Washington (DC): The Foundation. Available from: http://sleepfoundation.org/sleep-polls-data/sleep-in-america-poll/2011-technology-andsleep.

Raghunathan R. and M. T. Pham (1999). All Negative Moods Are Not Equal: Motivational Influences of Anxiety and Sadness on Decision Making, Organizational Behavior and Human Decision Processes, 79(1), pp. 56-77.

Russell C. A. and H. J. Schau (2014). When Narrative Brands End: the Impact of Narrative Closure and Consumption Sociality on Loss Accommodation, Journal of Consumer Research, 40, pp. 1039-1062.

Schwarz N. and H. Bless (1991). Happy and mindless, but sad and smart? The impact of affective states on analytic reasoning. In J. P. Forgas (Ed.), Emotion and social judgments (pp. 55-71). Elmsford, NY: Pergamon Press.

Schwarz N. and G. L. Clore (1983). Mood, misattribution, and judgments of well-being: Informative and directive functions of affective states, Journal of Personality and Social Psychology, 45, pp. 513523.

Schwarz N. and G. L. Clore (1988). How do I feel about it? The informative functions of affective states. In K. Fiedler and J. Forgas (Eds.), Affect, cognition and social behaviour (pp. 44-62). Göttingen, Federal Republic of Germany: Hogrefe.

Schwert G. W. (1990). Stock Returns and Real Activity: A Century of Evidence, Journal of Finance, 45, pp. $1237-1257$.

Sias R. W. and L. T. Starks (1997). Return autocorrelation and institutional investors, Journal of Financial economics, 46(1), pp. 103-131.

Todd. A. M. (2011). Saying Goodbye to Friends: Fan Culture as Lived Experience, Journal of Popular Culture, 44, pp. 854-871.

Tooby J. and L. Cosmides (2001). Does beauty build adapted minds? Toward an evolutionary theory of aesthetics, fiction and the arts, Substance, 94/95, pp. 6-27.

TVB (2012). TV basics: a report on the growth and scope of television, TVB Local Media Marketing Solutions. http://www.tvb.org/media/file/TV_Basics.pdf.

Webster J., P. Phalen, and L. Lichty (2014). Ratings Analysis: Audience Measurement and Analytics, Fourth Edition, New York: Routledge.

White H. (1980). A heteroskedastic-consistent covariance matrix estimator and a direct test of heteroskedasticity, Econometrica, 48, pp. 817-838.

Yuan K., L. Zheng, and Q. Zhu (2006). Are investors moonstruck? Lunar phases and stock returns, Journal of Empirical Finance, 13, pp. 1-23.

Zillmann D. (1988). Mood management through communication choices, American Behavioral Scientist, 31, pp. 327-340. 


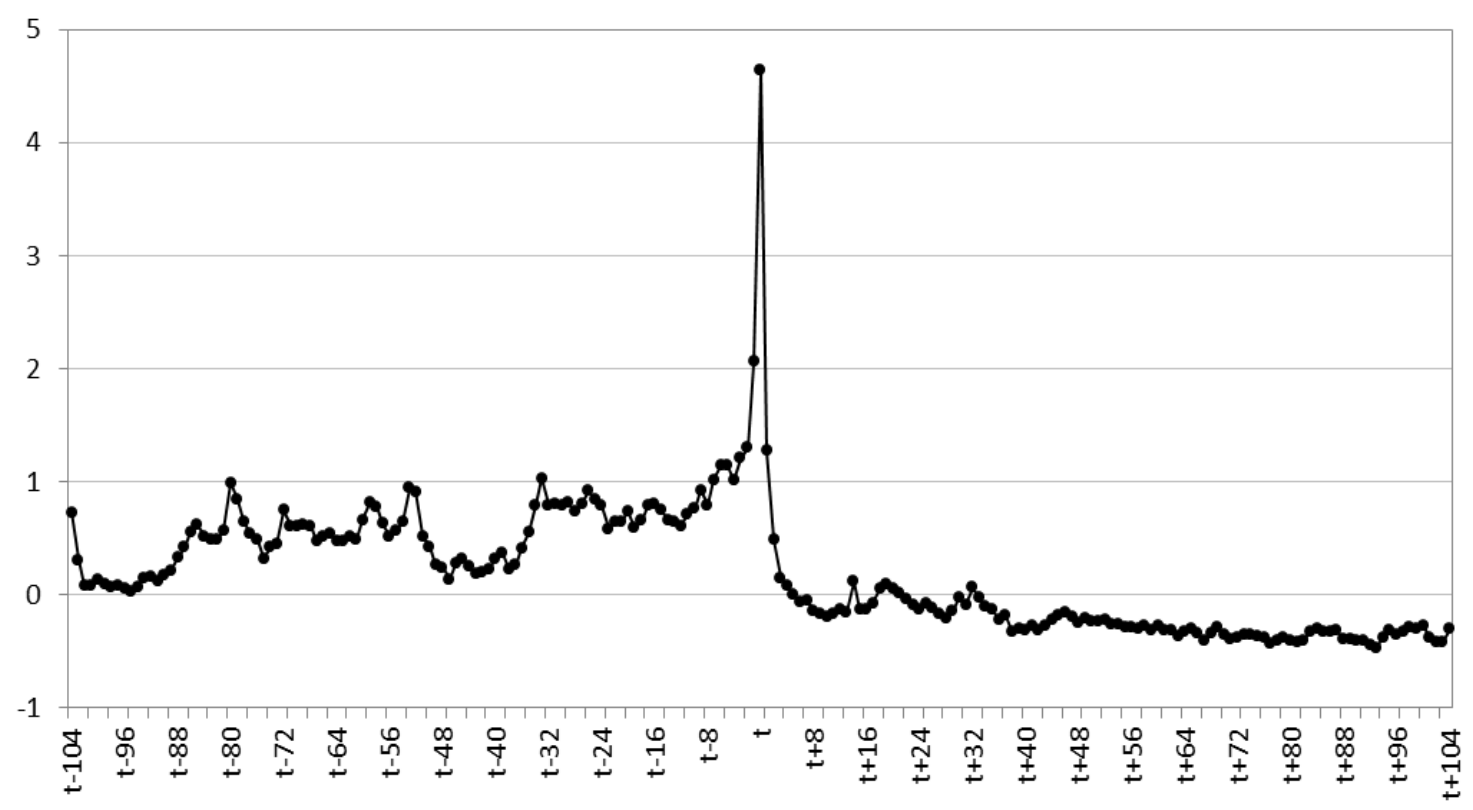

Figure 1. This figure plots the temporal pattern of weekly Google web search queries (in standard deviations from the mean) for the title of the typical major TV series. Only search queries generated within the U.S. are counted. Due to data availability reasons, the figure is constructed using data for a sub-sample of the TV series analyzed in this study. More specifically, this sub-sample consists of the 41 TV series that ended between January 2006 and July 2010 . Week $t$ represents the week in which the series finales aired. The amount of Google web search queries for a given TV series' title proxies for how intensely U.S. Internet users searched for information about that series within a given week, which is a measure of Americans' attention to the series itself. Search activity time series data for each of the 41 TV series were obtained from Google Correlate using as an input the title of the TV series. The search activity data that Google Correlate returns are "normalized by dividing by the total count for all queries in that week", which controls for the "growth in all Internet search use" [Mohebbi et al., 2011]. Google Correlate also automatically converts each time series into a standard score, so that it has a mean value of zero and a variance of one. Each data point in the figure represents the average standard score for a given week across the 41 TV series in the sub-sample. 


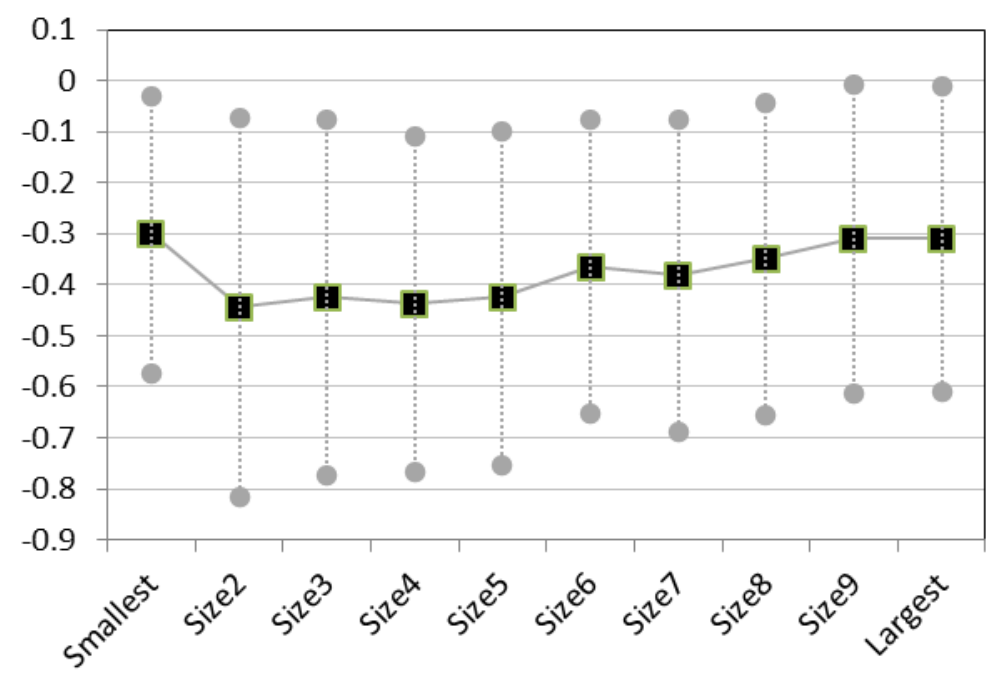

Figure 2. This figure displays $\beta_{2}$ 's point estimates (squares) and 95\% confidence intervals (circles) obtained from estimating regression model (3) for each of the ten (Fama-French) size portfolios.

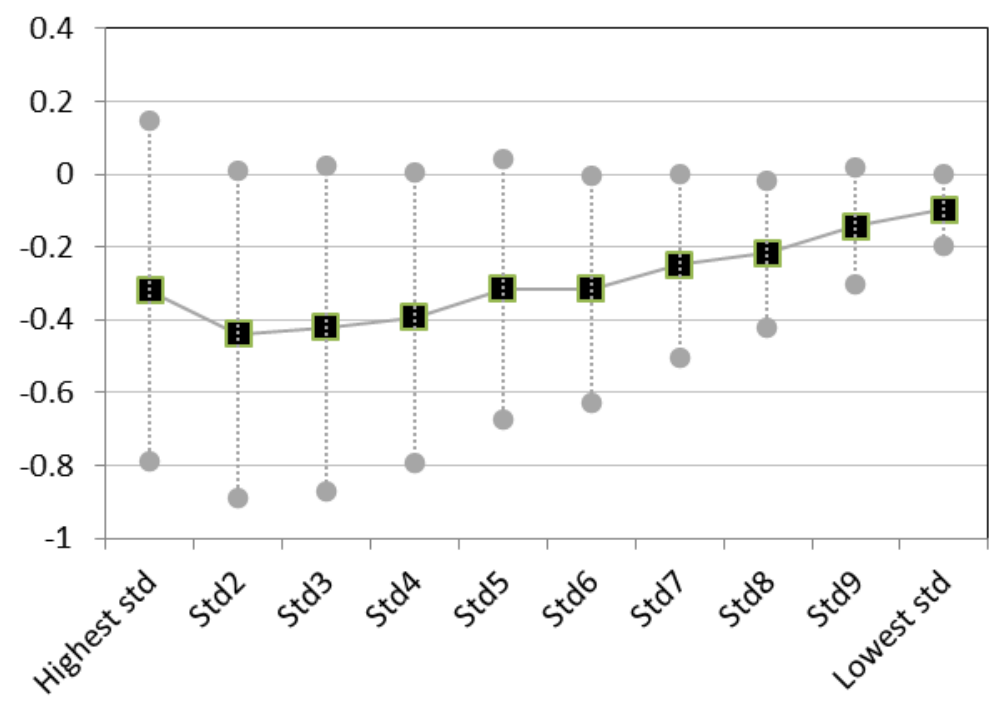

Figure 3. This figure displays $\beta_{2}$ 's point estimates (squares) and $95 \%$ confidence intervals (circles) obtained from estimating regression model (3) for each of the ten volatility-based portfolios. 


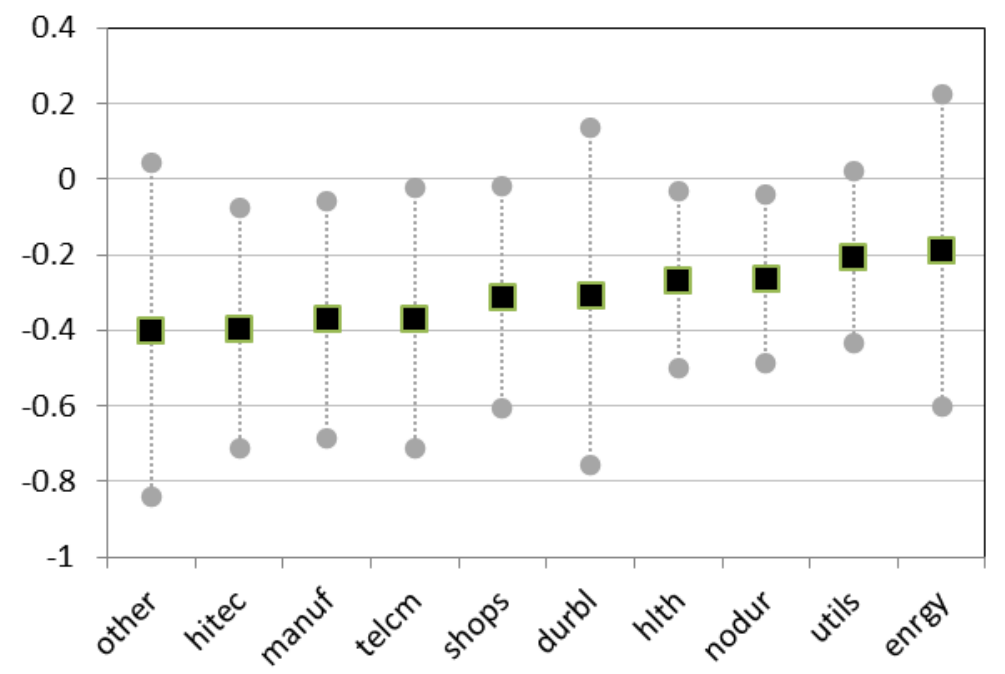

Figure 4. This figure displays $\beta_{2}$ 's point estimates (squares) and 95\% confidence intervals (circles) obtained from estimating regression model (3) for each of the ten (Fama-French) industry portfolios. 


\section{Table 1}

TV Series Finales - Summary Statistics

This table displays some summary statistics concerning the sample of TV series finales employed in the empirical analysis. The oldest finale was broadcast on August 29, 1967 (The Fugitive), and the most recent one aired on August 13, 2012 (The Closer). Though there are 159 finales in the sample, a few pairs of them aired on the same day or between two nonconsecutive trading days, leading to 147 event days (i.e. observations). If more than one finale aired on the same day or between two nonconsecutive trading days, I compute the total number of finale viewers by adding up the viewers of the relevant finales. I follow the same approach when calculating TV ratings and audience shares. Rating points measure the percentage of U.S. households owning a TV set that are tuned to a given program. Share points measure the percentage of U.S. households watching TV that are tuned to a given program. Rating and audience share data are missing for a handful of series finales. Panel A refers to the main dataset used throughout the empirical analysis, whereas Panel B refers to a second dataset that is analyzed in a robustness exercise in section 4.4.

\begin{tabular}{lcccccc}
\hline \hline & Observations & Mean & $\begin{array}{c}\text { Standard } \\
\text { Deviation }\end{array}$ & Median & Max & Min \\
\hline Panel A: Main dataset & & & & & & \\
\hline Viewers (millions) & 147 & 15.52 & 15.55 & 10.80 & 105.94 & 2.10 \\
Rating (\%) & 141 & 10.14 & 9.48 & 7.30 & 60.20 & 0.80 \\
Share (\%) & 141 & 16.67 & 14.40 & 13.00 & 77.00 & 2.00 \\
\hline Panel B: Alternative dataset (hand-collected from newspapers, magazines, and newsletters) & \\
\hline Rating (\%) & 131 & 10.56 & 9.63 & 7.50 & 60.30 & 1.30 \\
Share (\%) & 127 & 17.13 & 14.51 & 13.00 & 77.00 & 2.00 \\
\hline
\end{tabular}


Table 2

Stock Market Returns, Trading Volume, and Control Variables - Summary Statistics

Panel A of this table shows some summary statistics concerning the indices of the U.S. stock market employed in this study. Panel B shows some summary statistics about trading volume. Panel C displays some summary statistics concerning some of the control variables employed in the empirical analysis. Stock returns, the U.S. Treasury term premium, and the junk bond premium are expressed in percentage points.

\begin{tabular}{|c|c|c|c|c|c|}
\hline & Mean & $\begin{array}{c}\text { Standard } \\
\text { Deviation }\end{array}$ & Max & Min & Sample Period \\
\hline \multicolumn{6}{|l|}{ Panel A: Stock Returns } \\
\hline Nasdaq Composite & 0.033 & 1.262 & 13.255 & -12.048 & 2/8/1971-8/31/2012 \\
\hline NYSE Composite & 0.025 & 1.033 & 11.526 & -21.286 & $1 / 4 / 1967-8 / 31 / 2012$ \\
\hline S\&P500 & 0.025 & 1.066 & 10.957 & -22.899 & $1 / 4 / 1967-8 / 31 / 2012$ \\
\hline Russell 3000 & 0.024 & 1.203 & 10.863 & -20.391 & $9 / 11 / 1987-8 / 31 / 2012$ \\
\hline Russell 2000 & 0.025 & 1.342 & 8.860 & -13.381 & $9 / 11 / 1987-8 / 31 / 2012$ \\
\hline \multicolumn{6}{|c|}{ Panel B: Trading Volume (U.S. market) } \\
\hline $\begin{array}{l}\# \text { of constituent shares } \\
\text { traded (in millions) }\end{array}$ & $1,172.2$ & $1,657.2$ & $11,232.1$ & 2.2 & $1 / 2 / 1973-8 / 31 / 2012$ \\
\hline $\begin{array}{l}\# \text { of shares traded } \times \text { closing } \\
\text { price of each stock } \\
\text { (in millions of } \$ \text { ) }\end{array}$ & $39,101.1$ & $50,982.2$ & $307,455.2$ & 19.0 & $1 / 2 / 1973-8 / 31 / 2012$ \\
\hline \multicolumn{6}{|l|}{ Panel C: Control Variables } \\
\hline $\begin{array}{l}\text { U.S. Treasury Term } \\
\text { Premium }\end{array}$ & 1.538 & 1.305 & 5.412 & -3.728 & $1 / 4 / 1967-8 / 31 / 2012$ \\
\hline Junk Bond Premium & 0.991 & 0.405 & 3.500 & 0.500 & $1 / 2 / 1986-6 / 29 / 2012$ \\
\hline $\begin{array}{l}\text { Average daily temperature } \\
\text { in New York City }\left({ }^{\circ} \mathrm{F}\right)\end{array}$ & 55.06 & 17.15 & 93.60 & 2.30 & $1 / 4 / 1967-8 / 31 / 2012$ \\
\hline $\begin{array}{l}\text { Average daily wind speed } \\
\text { in New York City (Knots) }\end{array}$ & 10.08 & 3.32 & 32.80 & 1.80 & $1 / 4 / 1967-8 / 31 / 2012$ \\
\hline $\begin{array}{l}\text { Rainfall in New York City } \\
(\text { yes }=1 ; \text { no }=0)\end{array}$ & 0.36 & 0.48 & 1 & 0 & $1 / 4 / 1967-8 / 31 / 2012$ \\
\hline
\end{tabular}


Table 3

TV Series Finales and Stock Returns - Baseline Model

This table displays the coefficient estimates generated by fitting regression equation (1). $p$-values computed using Newey-West robust standard errors are shown in square brackets below the corresponding coefficients. The last row reports the $p$-values relative to the null hypothesis that the two coefficients of interest $\left(\beta_{1}\right.$ and $\left.\beta_{2}\right)$ are jointly equal to zero. One, two, and three asterisks denote statistical significance at the ten, five, and one percent level, respectively.

\begin{tabular}{|c|c|c|c|c|c|}
\hline Dep. Var.: & $\begin{array}{l}\text { Nasdaq } \\
\text { Comp }\end{array}$ & $\begin{array}{l}\text { NYSE } \\
\text { Comp }\end{array}$ & S\&P500 & $\begin{array}{c}\text { Russell } \\
3000\end{array}$ & $\begin{array}{c}\text { Russell } \\
2000\end{array}$ \\
\hline & (1) & (2) & (3) & (4) & (5) \\
\hline$\alpha$ & $\begin{array}{l}.149 * * * \\
{[0.002]}\end{array}$ & $\begin{array}{c}0.109 * * * \\
{[0.002]}\end{array}$ & $\begin{array}{l}.098 * * * \\
{[0.006]}\end{array}$ & $\begin{array}{l}.133^{* * *} \\
{[0.009]}\end{array}$ & $\begin{array}{l}.202 * * * \\
{[0.001]}\end{array}$ \\
\hline$\beta_{1}$ FINALE & $\begin{array}{c}1.282 * * * \\
{[0.003]}\end{array}$ & $\begin{array}{l}1.009 * * \\
{[0.025]}\end{array}$ & $\begin{array}{l}1.042 * * \\
{[0.014]}\end{array}$ & $\begin{array}{c}1.195 * * * \\
{[0.005]}\end{array}$ & $\begin{array}{c}1.406^{* * * *} \\
{[0.009]}\end{array}$ \\
\hline$\beta_{2}$ FINALE $\times \ln ($ VIEWERS $)$ & $\begin{array}{c}-.447 * * * \\
{[0.003]}\end{array}$ & $\begin{array}{l}-.326 * * \\
{[0.041]}\end{array}$ & $\begin{array}{l}-.332 * * \\
{[0.029]}\end{array}$ & $\begin{array}{c}-.421 * * * \\
{[0.005]}\end{array}$ & $\begin{array}{c}-.511 * * * \\
{[0.007]}\end{array}$ \\
\hline PRE & $\begin{array}{l}.154 * * \\
{[0.013]}\end{array}$ & $\begin{array}{l}.167 * * * \\
{[0.001]}\end{array}$ & $\begin{array}{l}.145^{* * *} \\
{[0.002]}\end{array}$ & $\begin{array}{c}.044 \\
{[0.535]}\end{array}$ & $\begin{array}{c}.115 \\
{[0.180]}\end{array}$ \\
\hline POST & $\begin{array}{c}-.020 \\
{[0.801]}\end{array}$ & $\begin{array}{c}.046 \\
{[0.436]}\end{array}$ & $\begin{array}{c}.028 \\
{[0.651]}\end{array}$ & $\begin{array}{c}.002 \\
{[0.981]}\end{array}$ & $\begin{array}{c}-.023 \\
{[0.814]}\end{array}$ \\
\hline MONDAY & $\begin{array}{c}-.232 * * * \\
{[0.001]}\end{array}$ & $\begin{array}{c}-.137 * * * \\
{[0.001]}\end{array}$ & $\begin{array}{c}-.116 * * * \\
{[0.001]}\end{array}$ & $\begin{array}{c}-.066 \\
{[0.220]}\end{array}$ & $\begin{array}{c}-.172 * * * \\
{[0.002]}\end{array}$ \\
\hline TUESDAY & $\begin{array}{c}-.112 * * * \\
{[0.004]}\end{array}$ & $\begin{array}{c}-.032 \\
{[0.273]}\end{array}$ & $\begin{array}{c}-.016 \\
{[0.605]}\end{array}$ & $\begin{array}{c}.004 \\
{[0.924]}\end{array}$ & $\begin{array}{c}-.039 \\
{[0.448]}\end{array}$ \\
\hline THURSDAY & $\begin{array}{c}-.014 \\
{[0.712]}\end{array}$ & $\begin{array}{c}-.055^{*} \\
{[0.054]}\end{array}$ & $\begin{array}{c}-.047 \\
{[0.111]}\end{array}$ & $\begin{array}{c}-.049 \\
{[0.285]}\end{array}$ & $\begin{array}{c}-.034 \\
{[0.517]}\end{array}$ \\
\hline FRIDAY & $\begin{array}{c}-.022 \\
{[0.553]}\end{array}$ & $\begin{array}{c}-.022 \\
{[0.438]}\end{array}$ & $\begin{array}{c}-.033 \\
{[0.255]}\end{array}$ & $\begin{array}{c}-.031 \\
{[0.484]}\end{array}$ & $\begin{array}{c}-.015 \\
{[0.763]}\end{array}$ \\
\hline JANUARY & $\begin{array}{c}.043 \\
{[0.466]}\end{array}$ & $\begin{array}{c}-.022 \\
{[0.615]}\end{array}$ & $\begin{array}{c}-.014 \\
{[0.747]}\end{array}$ & $\begin{array}{c}-.087 \\
{[0.171]}\end{array}$ & $\begin{array}{c}-.127 * \\
{[0.076]}\end{array}$ \\
\hline FEBRUARY & $\begin{array}{c}-.083 \\
{[0.140]}\end{array}$ & $\begin{array}{c}-.079 * \\
{[0.058]}\end{array}$ & $\begin{array}{c}-.080 * \\
{[0.060]}\end{array}$ & $\begin{array}{c}-.114^{*} \\
{[0.062]}\end{array}$ & $\begin{array}{c}-.118^{*} \\
{[0.091]}\end{array}$ \\
\hline MARCH & $\begin{array}{c}-.047 \\
{[0.409]}\end{array}$ & $\begin{array}{c}-.015 \\
{[0.729]}\end{array}$ & $\begin{array}{c}-.008 \\
{[0.860]}\end{array}$ & $\begin{array}{c}-.059 \\
{[0.337]}\end{array}$ & $\begin{array}{c}-.092 \\
{[0.199]}\end{array}$ \\
\hline APRIL & $\begin{array}{l}-.011 \\
{[0.863]}\end{array}$ & $\begin{array}{c}.004 \\
{[0.928]}\end{array}$ & $\begin{array}{c}.008 \\
{[0.863]}\end{array}$ & $\begin{array}{l}-.025 \\
{[0.697]}\end{array}$ & $\begin{array}{l}-.078 \\
{[0.299]}\end{array}$ \\
\hline MAY & $\begin{array}{c}-.070 \\
{[0.222]}\end{array}$ & $\begin{array}{c}-.077 * \\
{[0.073]}\end{array}$ & $\begin{array}{c}-.076^{*} \\
{[0.084]}\end{array}$ & $\begin{array}{c}-.078 \\
{[0.215]}\end{array}$ & $\begin{array}{c}-.118 \\
{[0.114]}\end{array}$ \\
\hline JUNE & $\begin{array}{c}-.047 \\
{[0.393]}\end{array}$ & $\begin{array}{l}-.061 \\
{[0.137]}\end{array}$ & $\begin{array}{l}-.054 \\
{[0.191]}\end{array}$ & $\begin{array}{l}-.128^{* *} \\
{[0.029]}\end{array}$ & $\begin{array}{l}-.154 * * \\
{[0.029]}\end{array}$ \\
\hline JULY & $\begin{array}{c}-.087 \\
{[0.130]}\end{array}$ & $\begin{array}{c}-.064 \\
{[0.138]}\end{array}$ & $\begin{array}{c}-.056 \\
{[0.200]}\end{array}$ & $\begin{array}{c}-.080 \\
{[0.204]}\end{array}$ & $\begin{array}{c}-.192 * * * \\
{[0.008]}\end{array}$ \\
\hline AUGUST & $\begin{array}{c}-.079 \\
{[0.180]}\end{array}$ & $\begin{array}{c}-.057 \\
{[0.197]}\end{array}$ & $\begin{array}{c}-.055 \\
{[0.225]}\end{array}$ & $\begin{array}{l}-.147 * * \\
{[0.023]}\end{array}$ & $\begin{array}{c}-.187 * * \\
{[0.015]}\end{array}$ \\
\hline SEPTEMBER & $\begin{array}{c}-.133 * * \\
{[0.026]}\end{array}$ & $\begin{array}{c}-.106^{* *} \\
{[0.024]}\end{array}$ & $\begin{array}{l}-.106^{* *} \\
{[0.026]}\end{array}$ & $\begin{array}{c}-.134 * * \\
{[0.046]}\end{array}$ & $\begin{array}{l}-.172 * * \\
{[0.025]}\end{array}$ \\
\hline OCTOBER & $\begin{array}{c}-.064 \\
{[0.371]}\end{array}$ & $\begin{array}{c}-.046 \\
{[0.426]}\end{array}$ & $\begin{array}{c}-.031 \\
{[0.594]}\end{array}$ & $\begin{array}{c}-.108 \\
{[0.221]}\end{array}$ & $\begin{array}{l}-.228 * * \\
{[0.023]}\end{array}$ \\
\hline NOVEMBER & $\begin{array}{c}-.016 \\
{[0.795]}\end{array}$ & $\begin{array}{c}-.017 \\
{[0.712]}\end{array}$ & $\begin{array}{c}-.012 \\
{[0.796]}\end{array}$ & $\begin{array}{c}-.069 \\
{[0.323]}\end{array}$ & $\begin{array}{c}-.116 \\
{[0.158]}\end{array}$ \\
\hline Observations & 10488 & 11489 & 11497 & 6299 & 6399 \\
\hline F stat & $4.06^{* * *}$ & $2.94 * * *$ & $2.24 * * *$ & 1.12 & $1.94 * * *$ \\
\hline $\begin{array}{l}\text { Joint significance test }\left(\beta_{1}=\beta_{2}=0\right) \\
\qquad p \text {-value: }\end{array}$ & $0.011 * *$ & $0.052 *$ & $0.022 * *$ & $0.019 * *$ & $0.024 * *$ \\
\hline
\end{tabular}


Table 4

TV Series Finales and Stock Returns - Controlling for Economic News

This table displays the coefficient estimates generated by fitting regression equation (2). An X marks the controls that are included in the model but whose coefficients are not reported here due to space limitations. $p$-values computed using Newey-West robust standard errors are shown in square brackets below the corresponding coefficients. The last row reports the $p$-values relative to the null hypothesis that the two coefficients of interest $\left(\beta_{1}\right.$ and $\left.\beta_{2}\right)$ are jointly equal to zero. One, two, and three asterisks denote statistical significance at the ten, five, and one percent level, respectively.

\begin{tabular}{|c|c|c|c|c|c|}
\hline Dep. Var.: & $\begin{array}{c}\text { Nasdaq } \\
\text { Comp }\end{array}$ & $\begin{array}{l}\text { NYSE } \\
\text { Comp }\end{array}$ & S\&P500 & Russell 3000 & Russell 2000 \\
\hline & (1) & (2) & (3) & (4) & (5) \\
\hline$\alpha$ & $\begin{array}{c}.146 \\
{[0.158]}\end{array}$ & $\begin{array}{c}.116 \\
{[0.183]}\end{array}$ & $\begin{array}{c}.112 \\
{[0.193]}\end{array}$ & $\begin{array}{c}.136 \\
{[0.128]}\end{array}$ & $\begin{array}{c}.160 \\
{[0.124]}\end{array}$ \\
\hline$\beta_{1}$ FINALE & $\begin{array}{c}1.349 * * * \\
{[0.003]}\end{array}$ & $\begin{array}{l}1.125^{* *} \\
{[0.012]}\end{array}$ & $\begin{array}{c}1.159 * * * \\
{[0.005]}\end{array}$ & $\begin{array}{c}1.198 * * * \\
{[0.005]}\end{array}$ & $\begin{array}{c}1.424 * * * \\
{[0.009]}\end{array}$ \\
\hline$\beta_{2}$ FINALExln(VIEWERS) & $\begin{array}{c}-.486^{* * * *} \\
{[0.002]}\end{array}$ & $\begin{array}{l}-.395 * * \\
{[0.012]}\end{array}$ & $\begin{array}{c}-.403 * * * \\
{[0.006]}\end{array}$ & $\begin{array}{c}-.418 * * * \\
{[0.005]}\end{array}$ & $\begin{array}{c}-.509 * * * \\
{[0.008]}\end{array}$ \\
\hline$r_{t-1}$ & $\begin{array}{c}.018 \\
{[0.422]}\end{array}$ & $\begin{array}{c}-.024 \\
{[0.293]}\end{array}$ & $\begin{array}{c}-.046 * * \\
{[0.029]}\end{array}$ & $\begin{array}{c}-.031 \\
{[0.170]}\end{array}$ & $\begin{array}{c}-.001 \\
{[0.973]}\end{array}$ \\
\hline TPRE & $\begin{array}{c}-.0001 \\
{[0.992]}\end{array}$ & $\begin{array}{c}-.013 \\
{[0.221]}\end{array}$ & $\begin{array}{c}-.012 \\
{[0.306]}\end{array}$ & $\begin{array}{c}-.009 \\
{[0.432]}\end{array}$ & $\begin{array}{c}.004 \\
{[0.771]}\end{array}$ \\
\hline JPRE & $\begin{array}{c}-.002 \\
{[0.972]}\end{array}$ & $\begin{array}{c}-.009 \\
{[0.897]}\end{array}$ & $\begin{array}{c}-.015 \\
{[0.825]}\end{array}$ & $\begin{array}{c}-.026 \\
{[0.724]}\end{array}$ & $\begin{array}{c}-.019 \\
{[0.827]}\end{array}$ \\
\hline FED'S BEIGE BOOK & $\begin{array}{c}.092 \\
{[0.356]}\end{array}$ & $\begin{array}{c}.093 \\
{[0.274]}\end{array}$ & $\begin{array}{c}.098 \\
{[0.246]}\end{array}$ & $\begin{array}{c}.106 \\
{[0.242]}\end{array}$ & $\begin{array}{c}.115 \\
{[0.271]}\end{array}$ \\
\hline INVENTORIES & $\begin{array}{c}-.275^{*} \\
{[0.068]}\end{array}$ & $\begin{array}{c}-.094 \\
{[0.396]}\end{array}$ & $\begin{array}{c}-.103 \\
{[0.368]}\end{array}$ & $\begin{array}{c}-.116 \\
{[0.315]}\end{array}$ & $\begin{array}{c}-.177 \\
{[0.182]}\end{array}$ \\
\hline CPI & $\begin{array}{c}-.015 \\
{[0.858]}\end{array}$ & $\begin{array}{c}-.016 \\
{[0.811]}\end{array}$ & $\begin{array}{c}-.005 \\
{[0.940]}\end{array}$ & $\begin{array}{c}.003 \\
{[0.971]}\end{array}$ & $\begin{array}{c}-.004 \\
{[0.961]}\end{array}$ \\
\hline EMPLOYMENT & $\begin{array}{c}.054 \\
{[0.574]}\end{array}$ & $\begin{array}{c}-.019 \\
{[0.781]}\end{array}$ & $\begin{array}{c}-.021 \\
{[0.789]}\end{array}$ & $\begin{array}{c}.007 \\
{[0.931]}\end{array}$ & $\begin{array}{c}-.056 \\
{[0.530]}\end{array}$ \\
\hline DURABLE GOODS & $\begin{array}{c}.037 \\
{[0.716]}\end{array}$ & $\begin{array}{c}.029 \\
{[0.665]}\end{array}$ & $\begin{array}{c}.026 \\
{[0.707]}\end{array}$ & $\begin{array}{c}.044 \\
{[0.530]}\end{array}$ & $\begin{array}{c}.052 \\
{[0.544]}\end{array}$ \\
\hline FOMC STATEMENTS & $\begin{array}{c}.613 * * * \\
{[0.002]}\end{array}$ & $\begin{array}{l}.449 * * * \\
{[0.001]}\end{array}$ & $\begin{array}{c}.434 * * * \\
{[0.002]}\end{array}$ & $\begin{array}{l}.459 * * * \\
{[0.001]}\end{array}$ & $\begin{array}{l}.592 * * * \\
{[0.001]}\end{array}$ \\
\hline GDP & $\begin{array}{c}-.005 \\
{[0.951]}\end{array}$ & $\begin{array}{c}.063 \\
{[0.308]}\end{array}$ & $\begin{array}{c}.015 \\
{[0.816]}\end{array}$ & $\begin{array}{c}.029 \\
{[0.660]}\end{array}$ & $\begin{array}{c}.126 \\
{[0.104]}\end{array}$ \\
\hline HOUSING STARTS & $\begin{array}{c}.042 \\
{[0.602]}\end{array}$ & $\begin{array}{c}.066 \\
{[0.262]}\end{array}$ & $\begin{array}{c}.069 \\
{[0.255]}\end{array}$ & $\begin{array}{c}.068 \\
{[0.273]}\end{array}$ & $\begin{array}{c}.052 \\
{[0.518]}\end{array}$ \\
\hline INDUSTRIAL PRODUCTION & $\begin{array}{c}-.008 \\
{[0.920]}\end{array}$ & $\begin{array}{c}.018 \\
{[0.770]}\end{array}$ & $\begin{array}{c}.038 \\
{[0.560]}\end{array}$ & $\begin{array}{c}.026 \\
{[0.704]}\end{array}$ & $\begin{array}{c}-.025 \\
{[0.749]}\end{array}$ \\
\hline RETAIL SALES & $\begin{array}{c}.131 \\
{[0.149]}\end{array}$ & $\begin{array}{c}.016 \\
{[0.813]}\end{array}$ & $\begin{array}{c}.025 \\
{[0.724]}\end{array}$ & $\begin{array}{c}.039 \\
{[0.597]}\end{array}$ & $\begin{array}{c}.058 \\
{[0.450]}\end{array}$ \\
\hline VEHICLE SALES & $\begin{array}{c}-.011 \\
{[0.931]}\end{array}$ & $\begin{array}{c}-.063 \\
{[0.514]}\end{array}$ & $\begin{array}{c}-.051 \\
{[0.596]}\end{array}$ & $\begin{array}{c}-.037 \\
{[0.702]}\end{array}$ & $\begin{array}{c}-.029 \\
{[0.797]}\end{array}$ \\
\hline PRE & $\begin{array}{c}.092 \\
{[0.317]}\end{array}$ & $\begin{array}{c}.087 \\
{[0.170]}\end{array}$ & $\begin{array}{c}.055 \\
{[0.431]}\end{array}$ & $\begin{array}{c}.048 \\
{[0.502]}\end{array}$ & $\begin{array}{c}.117 \\
{[0.170]}\end{array}$ \\
\hline POST & $\begin{array}{c}.021 \\
{[0.862]}\end{array}$ & $\begin{array}{c}.040 \\
{[0.641]}\end{array}$ & $\begin{array}{c}.052 \\
{[0.569]}\end{array}$ & $\begin{array}{c}.025 \\
{[0.786]}\end{array}$ & $\begin{array}{c}.047 \\
{[0.776]}\end{array}$ \\
\hline Weekday \& Month Dummies & $\mathrm{X}$ & $\mathrm{X}$ & $\mathrm{X}$ & $\mathrm{X}$ & $\mathrm{X}$ \\
\hline Observations & 6634 & 6631 & 6634 & 6212 & 6214 \\
\hline F stat & $1.44 * *$ & 1.31 & 1.23 & 1.20 & $1.83^{* * *}$ \\
\hline $\begin{array}{l}\text { Joint significance test }\left(\beta_{1}=\beta_{2}=0\right) \\
p \text {-value: }\end{array}$ & $0.009 * * *$ & $0.041 * *$ & $0.019 * *$ & $0.018^{* *}$ & $0.031^{* *}$ \\
\hline
\end{tabular}


Table 5

TV Series Finales and Stock Returns - Controlling for Alternative Mood Variables

This table displays the coefficient estimates generated by fitting regression equation (3). An X marks the controls that are included in the model but whose coefficients are not reported here due to space limitations. $p$-values computed using Newey-West robust standard errors are shown in square brackets below the corresponding coefficients. The last row reports the $p$-values relative to the null hypothesis that the two coefficients of interest $\left(\beta_{1}\right.$ and $\left.\beta_{2}\right)$ are jointly equal to zero. One, two, and three asterisks denote statistical significance at the ten, five, and one percent level, respectively.

\begin{tabular}{|c|c|c|c|c|c|}
\hline Dep. Var.: & $\begin{array}{c}\text { Nasdaq } \\
\text { Comp }\end{array}$ & $\begin{array}{l}\text { NYSE } \\
\text { Comp }\end{array}$ & S\&P500 & Russell 3000 & Russell 2000 \\
\hline & (1) & (2) & (3) & (4) & (5) \\
\hline$\alpha$ & $\begin{array}{c}-.165 \\
{[0.457]}\end{array}$ & $\begin{array}{c}-.061 \\
{[0.724]}\end{array}$ & $\begin{array}{c}-.087 \\
{[0.624]}\end{array}$ & $\begin{array}{c}-.195 \\
{[0.464]}\end{array}$ & $\begin{array}{c}-.334 \\
{[0.282]}\end{array}$ \\
\hline$\beta_{1}$ FINALE & $\begin{array}{c}1.270 * * * \\
{[0.003]}\end{array}$ & $\begin{array}{l}1.014 * * \\
{[0.025]}\end{array}$ & $\begin{array}{l}1.038 * * \\
{[0.014]}\end{array}$ & $\begin{array}{c}1.179 * * * \\
{[0.005]}\end{array}$ & $\begin{array}{c}1.402 * * * \\
{[0.008]}\end{array}$ \\
\hline$\beta_{2}$ FINALE $\times \ln ($ VIEWERS $)$ & $\begin{array}{c}-.444 * * * \\
{[0.003]}\end{array}$ & $\begin{array}{l}-.329 * * \\
{[0.041]}\end{array}$ & $\begin{array}{c}-.332 * * \\
{[0.029]}\end{array}$ & $\begin{array}{c}-.413 * * * \\
{[0.005]}\end{array}$ & $\begin{array}{c}-.506 * * * \\
{[0.006]}\end{array}$ \\
\hline FALL & $\begin{array}{c}-.185^{* * * *} \\
{[0.001]}\end{array}$ & $\begin{array}{l}-.094 * * \\
{[0.045]}\end{array}$ & $\begin{array}{c}-.091 * \\
{[0.061]}\end{array}$ & $\begin{array}{c}-.145^{* *} \\
{[0.039]}\end{array}$ & $\begin{array}{c}-.241 * * * \\
{[0.002]}\end{array}$ \\
\hline SAD & $\begin{array}{c}.089 \\
{[0.171]}\end{array}$ & $\begin{array}{c}.031 \\
{[0.553]}\end{array}$ & $\begin{array}{c}.028 \\
{[0.595]}\end{array}$ & $\begin{array}{c}.116 \\
{[0.152]}\end{array}$ & $\begin{array}{c}.197 * * \\
{[0.038]}\end{array}$ \\
\hline NEWMOON & $\begin{array}{c}.034 \\
{[0.263]}\end{array}$ & $\begin{array}{c}.036 \\
{[0.127]}\end{array}$ & $\begin{array}{c}.036 \\
{[0.135]}\end{array}$ & $\begin{array}{c}.051 \\
{[0.163]}\end{array}$ & $\begin{array}{c}.066 \\
{[0.118]}\end{array}$ \\
\hline FULLMOON & $\begin{array}{c}.023 \\
{[0.444]}\end{array}$ & $\begin{array}{c}.009 \\
{[0.696]}\end{array}$ & $\begin{array}{c}.016 \\
{[0.511]}\end{array}$ & $\begin{array}{c}.042 \\
{[0.240]}\end{array}$ & $\begin{array}{c}.045 \\
{[0.253]}\end{array}$ \\
\hline TEMP & $\begin{array}{c}.002 \\
{[0.273]}\end{array}$ & $\begin{array}{c}.001 \\
{[0.64]}\end{array}$ & $\begin{array}{c}.001 \\
{[0.413]}\end{array}$ & $\begin{array}{c}.001 \\
{[0.941]}\end{array}$ & $\begin{array}{c}.001 \\
{[0.682]}\end{array}$ \\
\hline WIND & $\begin{array}{c}.006 \\
{[0.133]}\end{array}$ & $\begin{array}{c}.007 * * \\
{[0.027]}\end{array}$ & $\begin{array}{c}.007 * * \\
{[0.023]}\end{array}$ & $\begin{array}{c}.005 \\
{[0.244]}\end{array}$ & $\begin{array}{c}.005 \\
{[0.352]}\end{array}$ \\
\hline RAIN & $\begin{array}{c}-.069 * * * \\
{[0.007]}\end{array}$ & $\begin{array}{c}-.037^{*} \\
{[0.072]}\end{array}$ & $\begin{array}{l}-.043 * * \\
{[0.045]}\end{array}$ & $\begin{array}{c}-.043 \\
{[0.185]}\end{array}$ & $\begin{array}{l}-.082 * * \\
{[0.021]}\end{array}$ \\
\hline$r_{t-1}$ & $\begin{array}{l}.052 * * * \\
{[0.006]}\end{array}$ & $\begin{array}{c}.041 * * \\
{[0.021]}\end{array}$ & $\begin{array}{c}.015 \\
{[0.383]}\end{array}$ & $\begin{array}{c}-.031 \\
{[0.152]}\end{array}$ & $\begin{array}{c}-.004 \\
{[0.884]}\end{array}$ \\
\hline TPRE & $\begin{array}{c}.017 * \\
{[0.088]}\end{array}$ & $\begin{array}{c}.008 \\
{[0.323]}\end{array}$ & $\begin{array}{c}.009 \\
{[0.260]}\end{array}$ & $\begin{array}{c}-.013 \\
{[0.284]}\end{array}$ & $\begin{array}{c}-.001 \\
{[0.925]}\end{array}$ \\
\hline Macro Announcements & $\mathrm{X}$ & $\mathrm{X}$ & $\mathrm{X}$ & $\mathrm{X}$ & $\mathrm{X}$ \\
\hline PRE & $\begin{array}{c}.116^{*} \\
{[0.067]}\end{array}$ & $\begin{array}{l}.157 * * * \\
{[0.001]}\end{array}$ & $\begin{array}{l}.136 * * * \\
{[0.005]}\end{array}$ & $\begin{array}{c}.009 \\
{[0.896]}\end{array}$ & $\begin{array}{c}.058 \\
{[0.502]}\end{array}$ \\
\hline POST & $\begin{array}{c}-.047 \\
{[0.562]}\end{array}$ & $\begin{array}{c}.029 \\
{[0.628]}\end{array}$ & $\begin{array}{c}.016 \\
{[0.796]}\end{array}$ & $\begin{array}{c}-.001 \\
{[0.997]}\end{array}$ & $\begin{array}{c}-.034 \\
{[0.747]}\end{array}$ \\
\hline Weekday \& Month Dummies & $\mathrm{X}$ & $X$ & $\mathrm{X}$ & $\mathrm{X}$ & $\mathrm{X}$ \\
\hline Observations & 10391 & 11361 & 11389 & 6283 & 6362 \\
\hline F stat & $3.60 * * *$ & $2.81 * * *$ & $2.11 * * *$ & $1.32 *$ & $2.17 * * *$ \\
\hline $\begin{array}{l}\text { Joint significance test }\left(\beta_{1}=\beta_{2}=0\right) \\
p \text {-value: }\end{array}$ & $0.013 * *$ & $0.054 *$ & $0.024 * *$ & $0.019 * *$ & $0.024 * *$ \\
\hline
\end{tabular}




\section{Table 6}

TV Series Finales and Stock Returns - Alternative TV Viewership Measures

This table displays the coefficient estimates generated by fitting a modified version of model (3). Column (a) shows the estimates obtained by replacing the number of viewers of a series finale with the finale's rating (percentage of U.S. households owning a TV set that are tuned to a given program). In column (b) the ratings come from an alternative dataset constructed by hand-collecting data from such secondary sources as newspapers and magazines (see Appendix A). An X marks the controls that are included in the model but whose coefficients are not reported here due to space limitations. $p$-values computed using Newey-West robust standard errors are shown in square brackets below the corresponding coefficients. The last row reports the $p$-values relative to the null hypothesis that the two coefficients of interest $\left(\beta_{1}\right.$ and $\left.\beta_{2}\right)$ are jointly equal to zero. One, two, and three asterisks denote statistical significance at the ten, five, and one percent level, respectively. TV ratings are measured in percentage points.

\begin{tabular}{|c|c|c|c|c|c|c|c|c|c|c|}
\hline \multirow[t]{2}{*}{ Dep. Var.: } & \multicolumn{2}{|c|}{ Nasdaq Comp } & \multicolumn{2}{|c|}{ NYSE Comp } & \multicolumn{2}{|c|}{ S\&P500 } & \multicolumn{2}{|c|}{ Russell 3000} & \multicolumn{2}{|c|}{ Russell 2000} \\
\hline & (1a) & (1b) & $(2 a)$ & (2b) & (3a) & (3b) & $(4 a)$ & (4b) & $(5 a)$ & $(5 b)$ \\
\hline$\alpha$ & $\begin{array}{c}-.17 \\
{[0.46]}\end{array}$ & $\begin{array}{c}-.16 \\
{[0.46]}\end{array}$ & $\begin{array}{c}-.06 \\
{[0.72]}\end{array}$ & $\begin{array}{c}-.06 \\
{[0.73]}\end{array}$ & $\begin{array}{c}-.09 \\
{[0.62]}\end{array}$ & $\begin{array}{c}-.09 \\
{[0.63]}\end{array}$ & $\begin{array}{c}-.19 \\
{[0.46]}\end{array}$ & $\begin{array}{c}-.19 \\
{[0.47]}\end{array}$ & $\begin{array}{c}-.34 \\
{[0.28]}\end{array}$ & $\begin{array}{c}-.33 \\
{[0.29]}\end{array}$ \\
\hline$\beta_{1}$ FINALE & $\begin{array}{c}1.28 * * * \\
{[0.01]}\end{array}$ & $\begin{array}{l}1.17 * * \\
{[0.01]}\end{array}$ & $\begin{array}{l}1.02 * * \\
{[0.02]}\end{array}$ & $\begin{array}{c}.93 * \\
{[0.05]}\end{array}$ & $\begin{array}{l}1.02 * * \\
{[0.01]}\end{array}$ & $\begin{array}{l}.91 * * \\
{[0.04]}\end{array}$ & $\begin{array}{c}1.19 * * * \\
{[0.01]}\end{array}$ & $\begin{array}{l}1.09 * * \\
{[0.02]}\end{array}$ & $\begin{array}{c}1.48 * * * \\
{[0.01]}\end{array}$ & $\begin{array}{l}1.41 * * \\
{[0.01]}\end{array}$ \\
\hline $\begin{array}{l}\beta_{2} \text { FINALEx } \\
\times \ln (\text { RATING) }\end{array}$ & $\begin{array}{c}-.51 * * * \\
{[0.01]}\end{array}$ & $\begin{array}{l}-.47 * * \\
{[0.01]}\end{array}$ & $\begin{array}{l}-.37 * * \\
{[0.04]}\end{array}$ & $\begin{array}{c}-.34 * \\
{[0.08]}\end{array}$ & $\begin{array}{l}-.37 * * \\
{[0.03]}\end{array}$ & $\begin{array}{c}-.32 * \\
{[0.07]}\end{array}$ & $\begin{array}{c}-.48 * * * \\
{[0.01]}\end{array}$ & $\begin{array}{l}-.44 * * \\
{[0.01]}\end{array}$ & $\begin{array}{c}-.60 * * * \\
{[0.01]}\end{array}$ & $\begin{array}{c}-.58 * * * \\
{[0.01]}\end{array}$ \\
\hline FALL & $\begin{array}{c}-.19 * * * \\
{[0.01]}\end{array}$ & $\begin{array}{c}-.19 * * * \\
{[0.01]}\end{array}$ & $\begin{array}{l}-.10 * * \\
{[0.04]}\end{array}$ & $\begin{array}{l}-.09 * * \\
{[0.05]}\end{array}$ & $\begin{array}{c}-.09 * \\
{[0.06]}\end{array}$ & $\begin{array}{c}-.09 * \\
{[0.06]}\end{array}$ & $\begin{array}{l}-.15 * * \\
{[0.04]}\end{array}$ & $\begin{array}{l}-.14 * * \\
{[0.04]}\end{array}$ & $\begin{array}{c}-.24 * * * \\
{[0.01]}\end{array}$ & $\begin{array}{c}-.24 * * * \\
{[0.01]}\end{array}$ \\
\hline SAD & $\begin{array}{l}.09 * * * \\
{[0.17]}\end{array}$ & $\begin{array}{c}.09 \\
{[0.17]}\end{array}$ & $\begin{array}{c}.03 \\
{[0.56]}\end{array}$ & $\begin{array}{c}.03 \\
{[0.56]}\end{array}$ & $\begin{array}{c}.03 \\
{[0.60]}\end{array}$ & $\begin{array}{c}.03 \\
{[0.60]}\end{array}$ & $\begin{array}{c}.12 \\
{[0.15]}\end{array}$ & $\begin{array}{c}.12 \\
{[0.16]}\end{array}$ & $\begin{array}{l}.20 * * \\
{[0.04]}\end{array}$ & $\begin{array}{l}.20 * * \\
{[0.04]}\end{array}$ \\
\hline NEWMOON & $\begin{array}{c}.03 \\
{[0.27]}\end{array}$ & $\begin{array}{c}.03 \\
{[0.26]}\end{array}$ & $\begin{array}{c}.04 \\
{[0.13]}\end{array}$ & $\begin{array}{c}.04 \\
{[0.13]}\end{array}$ & $\begin{array}{c}.04 \\
{[0.14]}\end{array}$ & $\begin{array}{c}.04 \\
{[0.14]}\end{array}$ & $\begin{array}{c}.05 \\
{[0.17]}\end{array}$ & $\begin{array}{c}.05 \\
{[0.17]}\end{array}$ & $\begin{array}{c}.07 \\
{[0.12]}\end{array}$ & $\begin{array}{c}.07 \\
{[0.12]}\end{array}$ \\
\hline FULLMOON & $\begin{array}{c}.02 \\
{[0.45]}\end{array}$ & $\begin{array}{c}.02 \\
{[0.45]}\end{array}$ & $\begin{array}{c}.01 \\
{[0.70]}\end{array}$ & $\begin{array}{c}.01 \\
{[0.71]}\end{array}$ & $\begin{array}{c}.02 \\
{[0.52]}\end{array}$ & $\begin{array}{c}.02 \\
{[0.52]}\end{array}$ & $\begin{array}{c}.04 \\
{[0.24]}\end{array}$ & $\begin{array}{c}.04 \\
{[0.24]}\end{array}$ & $\begin{array}{c}.05 \\
{[0.26]}\end{array}$ & $\begin{array}{c}.04 \\
{[0.26]}\end{array}$ \\
\hline TEMP & $\begin{array}{c}.01 \\
{[0.27]}\end{array}$ & $\begin{array}{c}.01 \\
{[0.27]}\end{array}$ & $\begin{array}{c}.01 \\
{[0.63]}\end{array}$ & $\begin{array}{c}.01 \\
{[0.64]}\end{array}$ & $\begin{array}{c}.01 \\
{[0.41]}\end{array}$ & $\begin{array}{c}.01 \\
{[0.41]}\end{array}$ & $\begin{array}{c}.01 \\
{[0.93]}\end{array}$ & $\begin{array}{c}.01 \\
{[0.95]}\end{array}$ & $\begin{array}{c}.01 \\
{[0.67]}\end{array}$ & $\begin{array}{c}.01 \\
{[0.69]}\end{array}$ \\
\hline WIND & $\begin{array}{c}.01 \\
{[0.13]}\end{array}$ & $\begin{array}{c}.01 \\
{[0.14]}\end{array}$ & $\begin{array}{l}.01 * * \\
{[0.03]}\end{array}$ & $\begin{array}{l}.01 * * \\
{[0.03]}\end{array}$ & $\begin{array}{l}.01 * * \\
{[0.02]}\end{array}$ & $\begin{array}{l}.01 * * \\
{[0.02]}\end{array}$ & $\begin{array}{c}.01 \\
{[0.24]}\end{array}$ & $\begin{array}{c}.01 \\
{[0.25]}\end{array}$ & $\begin{array}{c}.01 \\
{[0.34]}\end{array}$ & $\begin{array}{c}.01 \\
{[0.36]}\end{array}$ \\
\hline RAIN & $\begin{array}{c}-.07 * * * \\
{[0.01]}\end{array}$ & $\begin{array}{c}-.07 * * * \\
{[0.01]}\end{array}$ & $\begin{array}{c}-.04 * \\
{[0.07]}\end{array}$ & $\begin{array}{c}-.04 * \\
{[0.07]}\end{array}$ & $\begin{array}{l}-.04 * * \\
{[0.05]}\end{array}$ & $\begin{array}{l}-.04 * * \\
{[0.05]}\end{array}$ & $\begin{array}{c}-.04 \\
{[0.19]}\end{array}$ & $\begin{array}{c}-.04 \\
{[0.19]}\end{array}$ & $\begin{array}{l}-.08 * * \\
{[0.02]}\end{array}$ & $\begin{array}{l}-.08 * * \\
{[0.02]}\end{array}$ \\
\hline$r_{t-1}$ & $\begin{array}{l}.05 * * * \\
{[0.01]}\end{array}$ & $\begin{array}{l}.05 * * * \\
{[0.01]}\end{array}$ & $\begin{array}{l}.04 * * \\
{[0.02]}\end{array}$ & $\begin{array}{l}.04 * * \\
{[0.02]}\end{array}$ & $\begin{array}{c}.02 \\
{[0.38]}\end{array}$ & $\begin{array}{c}.01 \\
{[0.38]}\end{array}$ & $\begin{array}{c}-.03 \\
{[0.15]}\end{array}$ & $\begin{array}{c}-.03 \\
{[0.15]}\end{array}$ & $\begin{array}{c}-.01 \\
{[0.89]}\end{array}$ & $\begin{array}{c}-.01 \\
{[0.90]}\end{array}$ \\
\hline TPRE & $\begin{array}{c}.02 * \\
{[0.09]}\end{array}$ & $\begin{array}{c}.02 * \\
{[0.09]}\end{array}$ & $\begin{array}{c}.01 \\
{[0.33]}\end{array}$ & $\begin{array}{c}.01 \\
{[0.32]}\end{array}$ & $\begin{array}{c}.01 \\
{[0.27]}\end{array}$ & $\begin{array}{c}.01 \\
{[0.26]}\end{array}$ & $\begin{array}{c}-.01 \\
{[0.28]}\end{array}$ & $\begin{array}{c}-.01 \\
{[0.28]}\end{array}$ & $\begin{array}{c}-.01 \\
{[0.91]}\end{array}$ & $\begin{array}{c}-.01 \\
{[0.92]}\end{array}$ \\
\hline $\begin{array}{l}\text { Macro } \\
\text { Announcements }\end{array}$ & $\mathrm{X}$ & $\mathrm{X}$ & $\mathrm{X}$ & $\mathrm{X}$ & $\mathrm{X}$ & $\mathrm{X}$ & $\mathrm{X}$ & $\mathrm{X}$ & $\mathrm{X}$ & $\mathrm{X}$ \\
\hline PRE & $\begin{array}{c}.12 * \\
{[0.07]}\end{array}$ & $\begin{array}{c}.12 * \\
{[0.07]}\end{array}$ & $\begin{array}{l}.16^{* * * *} \\
{[0.01]}\end{array}$ & $\begin{array}{l}.16^{* * * *} \\
{[0.01]}\end{array}$ & $\begin{array}{l}.14 * * * \\
{[0.01]}\end{array}$ & $\begin{array}{l}.14 * * * \\
{[0.01]}\end{array}$ & $\begin{array}{c}.01 \\
{[0.89]}\end{array}$ & $\begin{array}{c}.01 \\
{[0.90]}\end{array}$ & $\begin{array}{c}.06 \\
{[0.50]}\end{array}$ & $\begin{array}{c}.06 \\
{[0.50]}\end{array}$ \\
\hline POST & $\begin{array}{c}-.05 \\
{[0.55]}\end{array}$ & $\begin{array}{c}-.05 \\
{[0.56]}\end{array}$ & $\begin{array}{c}.03 \\
{[0.64]}\end{array}$ & $\begin{array}{c}.03 \\
{[0.62]}\end{array}$ & $\begin{array}{c}.02 \\
{[0.81]}\end{array}$ & $\begin{array}{c}.02 \\
{[0.79]}\end{array}$ & $\begin{array}{c}-.01 \\
{[0.97]}\end{array}$ & $\begin{array}{c}-.01 \\
{[0.99]}\end{array}$ & $\begin{array}{c}-.04 \\
{[0.72]}\end{array}$ & $\begin{array}{c}-.03 \\
{[0.75]}\end{array}$ \\
\hline $\begin{array}{l}\text { Weekday \& Month } \\
\text { Dummies }\end{array}$ & $\mathrm{X}$ & $X$ & $\mathrm{X}$ & $\mathrm{X}$ & $\mathrm{X}$ & $\mathrm{X}$ & $\mathrm{X}$ & $\mathrm{X}$ & $\mathrm{X}$ & $X$ \\
\hline Observations & 10391 & 10391 & 11361 & 11361 & 11389 & 11389 & 6283 & 6283 & 6362 & 6362 \\
\hline F stat & $3.60 * * *$ & $3.53 * * *$ & $2.83 * * *$ & $2.77 * * *$ & $2.13 * * *$ & $2.06 * * *$ & $1.32 *$ & 1.27 & $2.19 * * *$ & $2.17 * * *$ \\
\hline $\begin{array}{c}\text { Joint significance } \\
\text { test }\left(\beta_{1}=\beta_{2}=0\right) \\
p \text {-value: }\end{array}$ & $0.01 * *$ & $0.04 * *$ & $0.03 * *$ & 0.10 & $0.01 * *$ & $0.07 *$ & $0.01 * *$ & $0.05^{* *}$ & $0.01 * *$ & $0.03 * *$ \\
\hline
\end{tabular}


Online Appendix A

Table A.1. Series finales: sources of TV rating and share data

\begin{tabular}{|c|c|c|c|c|c|c|}
\hline Series & $\begin{array}{l}\text { Finale } \\
\text { Date }\end{array}$ & $\begin{array}{c}\text { Rating } \\
\text { (Wikipedia) }\end{array}$ & $\begin{array}{c}\text { Share } \\
\text { (Wikipedia) }\end{array}$ & $\begin{array}{c}\text { Rating } \\
\text { (Secondary } \\
\text { Source) }\end{array}$ & $\begin{array}{c}\text { Share } \\
\text { (Secondary } \\
\text { Source) }\end{array}$ & Secondary Source \\
\hline The Fugitive, $A B C$ & 29/08/1967 & $45.9 \%$ & $72 \%$ & $45.9 \%$ & $72 \%^{\mathrm{a}}$ & The Tuscaloosa News - Nov. 26, 1980 \\
\hline$M * A * S * H, C B S$ & 28/02/1983 & $60.2 \%$ & $77 \%$ & $60.3 \%$ & $77 \%$ & Broadcasting - Vol. 104, No. 11 \\
\hline Magnum, P.I., CBS & 01/05/1988 & $32.0 \%$ & $48 \%$ & $32.0 \%$ & & The Associated Press - May 4, 1988 \\
\hline The Facts of Life, NBC & 07/05/1988 & $13.2 \%$ & $29 \%$ & $13.2 \%$ & $29 \%$ & Broadcasting - Vol. 114, No. 20 \\
\hline St. Elsewhere, NBC & $25 / 05 / 1988$ & $17.0 \%$ & $29 \%$ & $17.0 \%$ & $29 \%$ & Star-News - Jun 2, 1988 \\
\hline Dynasty, ABC & 11/05/1989 & $10.8 \%$ & $17 \%$ & $10.8 \%$ & $17 \%$ & Variety - May 24, 1989 \\
\hline Moonlighting, $A B C$ & 14/05/1989 & $5.7 \%$ & $10 \%$ & $5.7 \%$ & $10 \%$ & Variety - May 24, 1989 \\
\hline Family Ties, NBC & 14/05/1989 & $20.8 \%$ & $35 \%$ & $20.8 \%$ & $35 \%$ & Broadcasting - Vol. 116, No. 21 \\
\hline Miami Vice, NBC & 21/05/1989 & $14.7 \%$ & $23 \%$ & $14.7 \%$ & $23 \%$ & Variety - May 24, 1989 \\
\hline Kate \& Allie, CBS & 22/05/1989 & $11.9 \%$ & $20 \%$ & $11.9 \%$ & $20 \%$ & Broadcasting - Vol. 116, No. 23 \\
\hline Highway to Heaven, NBC & 04/08/1989 & $7.1 \%$ & $16 \%$ & $7.1 \%$ & $16 \%$ & Broadcasting - Vol. 117, No. 7 \\
\hline$A L F, N B C$ & 24/03/1990 & $13.1 \%$ & $24 \%$ & $13.1 \%$ & $24 \%$ & Variety - March 28, 1990 \\
\hline $227, \mathrm{NBC}$ & 06/05/1990 & $5.0 \%$ & $8 \%$ & $4.9 \%$ & $10 \%$ & Broadcasting - Vol. 118, No. 20 \\
\hline Falcon Crest, CBS & $17 / 05 / 1990$ & $9.3 \%$ & $15 \%$ & $9.3 \%$ & $15 \%$ & Variety - May 23, 1990 \\
\hline Newhart, CBS & 21/05/1990 & $18.7 \%$ & $29 \%$ & $18.7 \%$ & $29 \%$ & Variety - March 23, 1990 \\
\hline Mr. Belvedere, $A B C$ & 08/07/1990 & $8.5 \%$ & $16 \%$ & $8.5 \%$ & $16 \%$ & Broadcasting - Vol. 119, No. 3 \\
\hline Dallas, CBS & 03/05/1991 & $22.0 \%$ & $38 \%$ & $22.0 \%$ & $38 \%$ & Sarasota Herald-Tribune - May 2, 1992 \\
\hline Amen, NBC & 11/05/1991 & $8.3 \%$ & $19 \%$ & $8.3 \%$ & $19 \%$ & Broadcasting - Vol. 120 , No. 20 \\
\hline Who's the Boss?, ABC & 25/04/1992 & $12.7 \%$ & $24 \%$ & $12.7 \%$ & $24 \%$ & Broadcasting - Vol. 122, No. 13 \\
\hline Growing Pains, $A B C$ & 25/04/1992 & $13.3 \%$ & $24 \%$ & $13.3 \%$ & $24 \%$ & Broadcasting - Vol. 122, No. 13 \\
\hline MacGyver, ABC & 25/04/1992 & $13.8 \%$ & $26 \%$ & $13.8 \%$ & $26 \%$ & Broadcasting - Vol. 122, No. 13 \\
\hline The Cosby Show, NBC & $30 / 04 / 1992$ & $28.0 \%$ & $45 \%$ & $28.0 \%$ & $45 \%$ & Sarasota Herald-Tribune - May 2, 1992 \\
\hline Jake and the Fatman, CBS & 06/05/1992 & $12.9 \%$ & $20 \%$ & $12.9 \%$ & $20 \%$ & Broadcasting - Vol. 122, No. 21 \\
\hline The Golden Girls, NBC & 09/05/1992 & $18.9 \%$ & $38 \%$ & $18.9 \%$ & $38 \%$ & Los Angeles Times - May 13, 1992 \\
\hline $\begin{array}{l}\text { The Tonight Show Starring } \\
\text { Johnny Carson, NBC }\end{array}$ & 22/05/1992 & & & $27.9 \%$ & $63 \%$ & Broadcasting - Vol. 122, No. 23 \\
\hline Doogie Howser, M.D., ABC & 24/03/1993 & $9.2 \%$ & $14 \%$ & $9.2 \%$ & $14 \%$ & Broadcasting \& Cable - Vol. 123, No. 14 \\
\hline Major Dad, CBS & $16 / 04 / 1993$ & $12.6 \%$ & $20 \%$ & $12.6 \%$ & $20 \%$ & Variety - May 26, 1993 \\
\hline Quantum Leap, NBC & 05/05/1993 & $13.7 \%$ & $23 \%$ & $13.7 \%$ & $23 \%$ & Broadcasting \& Cable - Vol. 123 , No. 20 \\
\hline A Different World, NBC & 08/05/1993 & $6.6 \%$ & $14 \%$ & $6.6 \%$ & $14 \%$ & Broadcasting \& Cable - Vol. 123 , No. 20 \\
\hline The Wonder Years, ABC & 12/05/1993 & $13.9 \%$ & $23 \%$ & $13.9 \%$ & $23 \%$ & Variety - May 14, 1993 \\
\hline Knots Landing, CBS & $13 / 05 / 1993$ & $13.9 \%$ & $22 \%$ & $13.9 \%$ & $22 \%$ & Variety - May 17, 1993 \\
\hline Cheers, NBC & 20/05/1993 & $45.5 \%$ & $64 \%$ & $45.5 \%$ & $64 \%$ & New York Times - May 22, 1993 \\
\hline Life Goes On, ABC & 23/05/1993 & $8.9 \%$ & $17 \%$ & $8.9 \%$ & & Los Angeles Times - May 26, 1993 \\
\hline Designing Women, CBS & 24/05/1993 & $14.2 \%$ & $22 \%$ & $14.2 \%$ & $22 \%$ & Variety - May 26, 1993 \\
\hline L.A. Law, NBC & 19/05/1994 & $15.9 \%$ & $27 \%$ & $15.9 \%$ & $27 \%$ & Variety - May 23, 1994 \\
\hline Evening Shade, CBS & 23/05/1994 & $9.6 \%$ & $15 \%$ & $9.6 \%$ & $15 \%$ & Variety - May 25, 1994 \\
\hline $\begin{array}{l}\text { Star Trek: The Next } \\
\text { Generation, Syndication }\end{array}$ & 23/05/1994 & $20.0 \%$ & $34 \%$ & $17.4 \%$ & & New York Times - July 24, 1994 \\
\hline Empty Nest, NBC & 29/04/1995 & $8.7 \%$ & $17 \%$ & $8.7 \%$ & $17 \%$ & Variety - May 8, 1995 \\
\hline Matlock, ABC & 07/05/1995 & $13.2 \%$ & $20 \%$ & $13.2 \%$ & $20 \%$ & Variety - May 15, 1995 \\
\hline
\end{tabular}


Table A.1 - Continued

\begin{tabular}{|c|c|c|c|c|c|c|}
\hline Series & $\begin{array}{l}\text { Finale } \\
\text { Date }\end{array}$ & $\begin{array}{c}\text { Rating } \\
\text { (Wikipedia) }\end{array}$ & $\begin{array}{c}\text { Share } \\
\text { (Wikipedia) }\end{array}$ & $\begin{array}{c}\text { Rating } \\
\text { (Secondary } \\
\text { Source) }\end{array}$ & $\begin{array}{c}\text { Share } \\
\text { (Secondary } \\
\text { Source) }\end{array}$ & Secondary Source \\
\hline In the Heat of the Night, CBS & $16 / 05 / 1995$ & $10.9 \%$ & $17 \%$ & $10.9 \%$ & $17 \%$ & Variety - May 22, 1995 \\
\hline Full House, $A B C$ & 23/05/1995 & $14.6 \%$ & $25 \%$ & $14.6 \%$ & $25 \%$ & Variety - May 20, 1998 \\
\hline Picket Fences, CBS & 24/04/1996 & $8.2 \%$ & $14 \%$ & $6.5 \%$ & $11 \%$ & Broadcasting \& Cable - Vol. 126, No. 20 \\
\hline Sisters, NBC & 04/05/1996 & $7.1 \%$ & $14 \%$ & $7.4 \%$ & $14 \%$ & Broadcasting \& Cable - Vol. 126, No. 21 \\
\hline Murder, She Wrote, CBS & 19/05/1996 & $12.3 \%$ & $21 \%$ & $12.3 \%$ & $21 \%$ & Broadcasting \& Cable - Vol. 126, No. 23 \\
\hline $\begin{array}{l}\text { The Fresh Prince of Bel-Air, } \\
\text { NBC }\end{array}$ & 20/05/1996 & $13.1 \%$ & $22 \%$ & $13.1 \%$ & $22 \%$ & Variety - May 22, 1996 \\
\hline Martin, Fox & 01/05/1997 & $5.8 \%$ & $11 \%$ & $5.8 \%$ & $10 \%$ & Broadcasting \& Cable - Vol. 127 , No. 20 \\
\hline Married... with Children, Fox & 05/05/1997 & $10.0 \%$ & $16 \%$ & $10.0 \%$ & $16 \%$ & Variety - May 7, 1997 \\
\hline Coach, $A B C$ & $14 / 05 / 1997$ & $9.3 \%$ & $16 \%$ & $9.3 \%$ & $16 \%$ & Broadcasting \& Cable - Vol. 127 , No. 22 \\
\hline Roseanne, $A B C$ & 20/05/1997 & $11.6 \%$ & $19 \%$ & $11.6 \%$ & $19 \%$ & Variety - May 22, 1997 \\
\hline Wings, NBC & $21 / 05 / 1997$ & $10.2 \%$ & $16 \%$ & $10.2 \%$ & $16 \%$ & Variety - May 20, 1998 \\
\hline Grace Under Fire, $A B C$ & $17 / 02 / 1998$ & $7.4 \%$ & $11 \%$ & $7.4 \%$ & $11 \%$ & Variety - February 23, 1998 \\
\hline Ellen, $A B C$ & $13 / 05 / 1998$ & $7.1 \%$ & $11 \%$ & $7.1 \%$ & $11 \%$ & Broadcasting \& Cable - Vol. 128 , No. 22 \\
\hline Seinfeld, NBC & $14 / 05 / 1998$ & $41.3 \%$ & $58 \%$ & $41.3 \%$ & $58 \%$ & New York Times - May 16, 1998 \\
\hline $\begin{array}{l}\text { Dr. Quinn, Medicine Woman, } \\
\text { CBS }\end{array}$ & $16 / 05 / 1998$ & $6.7 \%$ & $15 \%$ & $6.7 \%$ & $15 \%$ & Broadcasting \& Cable - Vol. 128 , No. 22 \\
\hline Murphy Brown, CBS & $18 / 05 / 1998$ & $12.3 \%$ & $19 \%$ & $12.3 \%$ & $19 \%$ & Variety - May 25, 1998 \\
\hline Step by Step, CBS & 26/06/1998 & $4.3 \%$ & $8 \%$ & $4.8 \%$ & $10 \%$ & Broadcasting \& Cable - Vol. 128 , No. 28 \\
\hline Family Matters, CBS & $17 / 07 / 1998$ & $4.5 \%$ & $8 \%$ & $4.5 \%$ & $10 \%$ & Broadcasting \& Cable - Vol. 128 , No. 31 \\
\hline Caroline in the City, NBC & 26/04/1999 & $6.3 \%$ & $10 \%$ & $6.3 \%$ & $10 \%$ & Variety - April 28, 1999 \\
\hline NewsRadio, NBC & 04/05/1999 & $6.5 \%$ & $11 \%$ & $6.5 \%$ & $11 \%$ & Broadcasting \& Cable - Vol. 129, No. 21 \\
\hline The Nanny, CBS & $12 / 05 / 1999$ & $8.1 \%$ & $14 \%$ & $8.1 \%$ & $14 \%$ & Variety - May 14, 1999 \\
\hline $\begin{array}{l}\text { Homicide: Life on the Street, } \\
\text { NBC }\end{array}$ & 21/05/1999 & $8.4 \%$ & $15 \%$ & $8.4 \%$ & $15 \%$ & Broadcasting \& Cable - Vol. 129, No. 23 \\
\hline Sister, Sister, WB & 23/05/1999 & $3.3 \%$ & $6 \%$ & $3.5 \%$ & $6 \%$ & Broadcasting \& Cable - Vol. 129, No. 23 \\
\hline Melrose Place, Fox & 24/05/1999 & $7.3 \%$ & $12 \%$ & $7.3 \%$ & $12 \%$ & Broadcasting \& Cable - Vol. 129, No. 24 \\
\hline Mad About You, NBC & 24/05/1999 & $13.6 \%$ & $20 \%$ & $13.6 \%$ & $20 \%$ & Variety - May 26, 1999 \\
\hline Home Improvement, $A B C$ & 25/05/1999 & $21.6 \%$ & $43 \%$ & $21.6 \%$ & $34 \%$ & Broadcasting \& Cable - Vol. 129, No. 24 \\
\hline Cosby, CBS & $28 / 04 / 2000$ & $5.2 \%$ & $10 \%$ & $5.2 \%$ & $10 \%$ & Broadcasting \& Cable - Vol. 130 , No. 20 \\
\hline Party of Five, Fox & 03/05/2000 & $4.8 \%$ & $8 \%$ & $4.8 \%$ & $8 \%$ & Broadcasting \& Cable - Vol. 130, No. 21 \\
\hline Chicago Hope, CBS & $04 / 05 / 2000$ & $5.8 \%$ & $9 \%$ & $5.8 \%$ & $9 \%$ & Broadcasting \& Cable - Vol. 130, No. 21 \\
\hline Boy Meets World, ABC & $05 / 05 / 2000$ & $6.1 \%$ & $12 \%$ & $6.1 \%$ & $12 \%$ & Broadcasting \& Cable - Vol. 130, No. 21 \\
\hline Profiler, NBC & $06 / 05 / 2000$ & $5.2 \%$ & $10 \%$ & $5.2 \%$ & $10 \%$ & Broadcasting \& Cable - Vol. 130, No. 21 \\
\hline The Pretender, NBC & $13 / 05 / 2000$ & $6.2 \%$ & $12 \%$ & $6.2 \%$ & $12 \%$ & Broadcasting \& Cable - Vol. 130 , No. 22 \\
\hline Beverly Hills, 90210, Fox & $17 / 05 / 2000$ & $11.9 \%$ & $21 \%$ & $9.6 \%$ & $15 \%$ & Broadcasting \& Cable - Vol. 130, No. 23 \\
\hline Nash Bridges, CBS & 04/05/2001 & $6.3 \%$ & $12 \%$ & $6.3 \%$ & $12 \%$ & Broadcasting \& Cable - Vol. 131, No. 21 \\
\hline Diagnosis: Murder, CBS & $11 / 05 / 2001$ & $4.9 \%$ & $10 \%$ & $4.9 \%$ & $10 \%$ & Broadcasting \& Cable - Vol. 131, No. 22 \\
\hline Walker, Texas Ranger, CBS & $19 / 05 / 2001$ & $6.8 \%$ & $13 \%$ & $6.8 \%$ & $13 \%$ & Broadcasting \& Cable - Vol. 131, No. 23 \\
\hline 3rd Rock from the Sun, NBC & $22 / 05 / 2001$ & $7.9 \%$ & $13 \%$ & $7.9 \%$ & $13 \%$ & Broadcasting \& Cable - Vol. 131, No. 24 \\
\hline Star Trek: Voyager, UPN & $23 / 05 / 2001$ & $5.5 \%$ & $9 \%$ & $5.5 \%$ & $9 \%$ & Broadcasting \& Cable - Vol. 131, No. 24 \\
\hline Dharma \& Greg, ABC & $30 / 04 / 2002$ & $4.7 \%$ & $8 \%$ & $4.7 \%$ & $8 \%$ & Broadcasting \& Cable - Vol. 132, No. 20 \\
\hline Spin City, $A B C$ & $30 / 04 / 2002$ & $4.8 \%$ & $7 \%$ & $4.8 \%$ & $7 \%$ & Broadcasting \& Cable - Vol. 132 , No. 20 \\
\hline
\end{tabular}


Table A.1 - Continued

\begin{tabular}{|c|c|c|c|c|c|c|}
\hline Series & $\begin{array}{l}\text { Finale } \\
\text { Date }\end{array}$ & $\begin{array}{c}\text { Rating } \\
\text { (Wikipedia) }\end{array}$ & $\begin{array}{c}\text { Share } \\
\text { (Wikipedia) }\end{array}$ & $\begin{array}{c}\text { Rating } \\
\text { (Secondary } \\
\text { Source) }\end{array}$ & $\begin{array}{c}\text { Share } \\
\text { (Secondary } \\
\text { Source) }\end{array}$ & Secondary Source \\
\hline The X-Files, Fox & $19 / 05 / 2002$ & $7.9 \%$ & $12 \%$ & $7.5 \%$ & $12 \%$ & Broadcasting \& Cable - Vol. 132, No. 22 \\
\hline Ally McBeal, Fox & $20 / 05 / 2002$ & $7.5 \%$ & $11 \%$ & $7.5 \%$ & $11 \%$ & Broadcasting \& Cable - Vol. 132, No. 23 \\
\hline Felicity, WB & $22 / 05 / 2002$ & $2.6 \%$ & $4 \%$ & $2.5 \%$ & $4 \%$ & Broadcasting \& Cable - Vol. 132, No. 23 \\
\hline Providence, NBC & $20 / 12 / 2002$ & $9.0 \%$ & $16 \%$ & $9.0 \%$ & & Daily Herald - December 27, 2002 \\
\hline Touched by an Angel, CBS & $27 / 04 / 2003$ & $8.9 \%$ & $15 \%$ & $8.9 \%$ & $15 \%$ & Media Life Magazine - April 30, 2003 \\
\hline Becker, CBS & $28 / 01 / 2004$ & $7.3 \%$ & $11 \%$ & $7.9 \%$ & $12 \%$ & Cynopsis - January 30, 2004 \\
\hline$E d, N B C$ & $06 / 02 / 2004$ & $5.8 \%$ & $10 \%$ & $5.7 \%$ & $9 \%$ & Cynopsis - February 9, 2004 \\
\hline Sex and the City, HBO & $22 / 02 / 2004$ & & & $6.5 \%$ & $10 \%$ & Broadcasting \& Cable - February 24, 2004 \\
\hline The District, CBS & $01 / 05 / 2004$ & $6.6 \%$ & $12 \%$ & $6.7 \%$ & $12 \%$ & Cynopsis - May 3, 2004 \\
\hline Friends, NBC & $06 / 05 / 2004$ & $29.8 \%$ & $43 \%$ & $29.2 \%$ & $42 \%$ & Broadcasting \& Cable - May 7, 2004 \\
\hline The Parkers, UPN & $10 / 05 / 2004$ & $2.8 \%$ & $5 \%$ & $2.8 \%$ & $5 \%$ & Cynopsis - May 12, 2004 \\
\hline Frasier, NBC & $13 / 05 / 2004$ & $16.3 \%$ & $25 \%$ & $16.3 \%$ & $25 \%$ & Chicago Tribune - May 15, 2004 \\
\hline The Practice, $A B C$ & $16 / 05 / 2004$ & $7.5 \%$ & $13 \%$ & $7.5 \%$ & $13 \%$ & Media Life Magazine - May 19, 2004 \\
\hline Angel, WB & $19 / 05 / 2004$ & $3.3 \%$ & $5 \%$ & $3.3 \%$ & $5 \%$ & Cynopsis - May 21, 2004 \\
\hline $\begin{array}{l}\text { The Drew Carey Show, } \\
A B C\end{array}$ & 08/09/2004 & $3.7 \%$ & $7 \%$ & $3.7 \%$ & $6 \%$ & Cynopsis - September 10, 2004 \\
\hline NYPD Blue, $A B C$ & $01 / 03 / 2005$ & $10.4 \%$ & $17 \%$ & $10.4 \%$ & $17 \%$ & Media Life Magazine - March 9, 2005 \\
\hline JAG, CBS & $29 / 04 / 2005$ & $9.0 \%$ & $15 \%$ & $9.0 \%$ & $15 \%$ & CBS Press Release - May 3, 2005 \\
\hline Judging Amy, CBS & 03/05/2005 & $7.6 \%$ & $12 \%$ & $7.6 \%$ & $12 \%$ & Cynopsis - May 5, 2005 \\
\hline Third Watch, NBC & $06 / 05 / 2005$ & $6.1 \%$ & $11 \%$ & $6.0 \%$ & $11 \%$ & Cynopsis - May 9, 2005 \\
\hline Star Trek: Enterprise, UPN & $13 / 05 / 2005$ & $2.2 \%$ & $4 \%$ & $2.1 \%$ & $4 \%$ & Cynopsis - May 16, 2005 \\
\hline $\begin{array}{l}\text { Everybody Loves } \\
\text { Raymond, CBS }\end{array}$ & $16 / 05 / 2005$ & $20.2 \%$ & $29 \%$ & $20.2 \%$ & $29 \%$ & Media Life Magazine - May 25, 2005 \\
\hline My Wife and Kids, ABC & $17 / 05 / 2005$ & $4.2 \%$ & $7 \%$ & $4.1 \%$ & $7 \%$ & Cynopsis - May 19, 2005 \\
\hline Yes, Dear, CBS & $15 / 02 / 2006$ & $4.4 \%$ & $6 \%$ & $4.8 \%$ & $7 \%$ & Cynopsis - February 17, 2006 \\
\hline Joey, NBC & $07 / 03 / 2006$ & $2.5 \%$ & $4 \%$ & $2.9 \%$ & $4 \%$ & Cynopsis - March 9, 2006 \\
\hline $\begin{array}{l}\text { Malcolm in the Middle, } \\
\text { Fox }\end{array}$ & $14 / 05 / 2006$ & $4.8 \%$ & $7 \%$ & $4.3 \%$ & $7 \%$ & Cynopsis - May 16, 2006 \\
\hline The West Wing, NBC & $14 / 05 / 2006$ & $6.2 \%$ & $10 \%$ & $6.1 \%$ & $10 \%$ & Cynopsis - May 16, 2006 \\
\hline That '70s Show, Fox & $18 / 05 / 2006$ & $6.0 \%$ & $10 \%$ & $5.5 \%$ & $9 \%$ & Cynopsis - May 22, 2006 \\
\hline Will \& Grace, NBC & $18 / 05 / 2006$ & $11.7 \%$ & $18 \%$ & $11.7 \%$ & $18 \%$ & Media Life Magazine - May 23, 2006 \\
\hline Charmed, WB & $21 / 05 / 2006$ & $2.8 \%$ & $5 \%$ & $2.7 \%$ & $4 \%$ & Cynopsis - May 23, 2006 \\
\hline Alias, $A B C$ & $22 / 05 / 2006$ & $4.5 \%$ & $7 \%$ & $4.5 \%$ & $7 \%$ & Cynopsis - May 24, 2006 \\
\hline Everwood, WB & $05 / 06 / 2006$ & $2.6 \%$ & $4 \%$ & $2.6 \%$ & $4 \%$ & Cynopsis - June 7, 2006 \\
\hline Reba, CW & $18 / 02 / 2007$ & $2.8 \%$ & $5 \%$ & $2.5 \%$ & $4 \%$ & Cynopsis - February 20, 2007 \\
\hline The O.C., Fox & $22 / 02 / 2007$ & $4.5 \%$ & $6 \%$ & $4.3 \%$ & $6 \%$ & Cynopsis - February 26, 2007 \\
\hline George Lopez, ABC & 08/05/2007 & $3.1 \%$ & $5 \%$ & $3.2 \%$ & $5 \%$ & Cynopsis - May 10, 2007 \\
\hline 7th Heaven, CW & $13 / 05 / 2007$ & $2.1 \%$ & $4 \%$ & $2.1 \%$ & $4 \%$ & Cynopsis - May 15, 2007 \\
\hline The King of Queens, CBS & $14 / 05 / 2007$ & $8.8 \%$ & $13 \%$ & $8.8 \%$ & $13 \%$ & Media Life Magazine - May 22, 2007 \\
\hline Gilmore Girls, CW & $15 / 05 / 2007$ & $3.1 \%$ & $5 \%$ & $3.0 \%$ & $5 \%$ & Cynopsis - May 17, 2007 \\
\hline Crossing Jordan, NBC & $16 / 05 / 2007$ & $4.3 \%$ & $7 \%$ & $4.2 \%$ & $7 \%$ & Cynopsis - May 18, 2007 \\
\hline Veronica Mars, CW & $22 / 05 / 2007$ & $0.8 \%$ & $2 \%$ & $1.3 \%$ & $2 \%$ & Cynopsis - May 24, 2007 \\
\hline Las Vegas, NBC & $15 / 02 / 2008$ & $5.0 \%$ & $9 \%$ & $5.0 \%$ & $9 \%$ & Cynopsis - February 18, 2008 \\
\hline
\end{tabular}


Table A.1 - Continued

\begin{tabular}{|c|c|c|c|c|c|c|}
\hline Series & $\begin{array}{l}\text { Finale } \\
\text { Date }\end{array}$ & $\begin{array}{c}\text { Rating } \\
\text { (Wikipedia) }\end{array}$ & $\begin{array}{c}\text { Share } \\
\text { (Wikipedia) }\end{array}$ & $\begin{array}{c}\text { Rating } \\
\text { (Secondary } \\
\text { Source) }\end{array}$ & $\begin{array}{c}\text { Share } \\
\text { (Secondary } \\
\text { Source) }\end{array}$ & Secondary Source \\
\hline Boston Legal, ABC & $08 / 12 / 2008$ & $6.2 \%$ & $10 \%$ & $6.2 \%$ & $10 \%$ & Cynopsis - December 10, 2008 \\
\hline Battlestar Galactica, Syfy & 20/03/2009 & $1.4 \%$ & $3 \%$ & $1.7 \%$ & & Broadcasting \& Cable - March 21, 2009 \\
\hline$E R, N B C$ & 02/04/2009 & $10.4 \%$ & $17 \%$ & $10.4 \%$ & $17 \%$ & Media Life Magazine - April 7, 2009 \\
\hline The Unit, CBS & $10 / 05 / 2009$ & $5.8 \%$ & $10 \%$ & $5.8 \%$ & $10 \%$ & Cynopsis - May 13, 2009 \\
\hline My Name Is Earl, NBC & $14 / 05 / 2009$ & $3.2 \%$ & $6 \%$ & $3.2 \%$ & $6 \%$ & Cynopsis - May 18, 2009 \\
\hline Prison Break, Fox & $15 / 05 / 2009$ & $2.0 \%$ & $4 \%$ & $2.0 \%$ & $4 \%$ & Cynopsis - May 19, 2009 \\
\hline Without a Trace, CBS & $19 / 05 / 2009$ & $7.3 \%$ & $12 \%$ & $7.3 \%$ & $12 \%$ & Media Life Magazine - May 28, 2009 \\
\hline According to Jim, $A B C$ & 02/06/2009 & $2.5 \%$ & $4 \%$ & $2.5 \%$ & $4 \%$ & Cynopsis - June 4, 2009 \\
\hline King of the Hill, Fox & $13 / 09 / 2009$ & $3.5 \%$ & $5 \%$ & $3.5 \%$ & $5 \%$ & Cynopsis - September 16, 2009 \\
\hline Dollhouse, Fox & $29 / 01 / 2010$ & $0.8 \%$ & $3 \%$ & $1.4 \%$ & $2 \%$ & Cynopsis - February 2, 2010 \\
\hline Heroes, NBC & $08 / 02 / 2010$ & $2.8 \%$ & $4 \%$ & $2.8 \%$ & $4 \%$ & Cynopsis - February 10, 2010 \\
\hline Numb3rs, CBS & $12 / 03 / 2010$ & $5.1 \%$ & $9 \%$ & $5.1 \%$ & $9 \%$ & Cynopsis - March 16, 2010 \\
\hline Scrubs, ABC & $17 / 03 / 2010$ & $2.3 \%$ & $4 \%$ & $2.3 \%$ & $4 \%$ & Cynopsis - March 19, 2010 \\
\hline Ugly Betty, ABC & $14 / 04 / 2010$ & $4.2 \%$ & $7 \%$ & $3.7 \%$ & $7 \%$ & Cynopsis - April 16, 2010 \\
\hline Cold Case, CBS & $02 / 05 / 2010$ & $6.4 \%$ & $11 \%$ & $6.4 \%$ & $11 \%$ & Media Life Magazine - May 4, 2010 \\
\hline $\begin{array}{l}\text { The New Adventures of Old } \\
\text { Christine, CBS }\end{array}$ & $12 / 05 / 2010$ & $4.6 \%$ & $6 \%$ & $4.5 \%$ & $8 \%$ & Cynopsis - May 14, 2010 \\
\hline Ghost Whisperer, CBS & $21 / 05 / 2010$ & $4.4 \%$ & $9 \%$ & $4.4 \%$ & $9 \%$ & Cynopsis - May 25, 2010 \\
\hline Lost, ABC & $23 / 05 / 2010$ & $7.5 \%$ & $13 \%$ & $7.5 \%$ & $13 \%$ & Media Life Magazine - May 25, 2010 \\
\hline Law \& Order, NBC & $24 / 05 / 2010$ & $5.1 \%$ & $9 \%$ & $5.1 \%$ & $9 \%$ & Cynopsis - May 26, 2010 \\
\hline 24, Fox & $24 / 05 / 2010$ & $5.2 \%$ & $8 \%$ & $5.2 \%$ & $8 \%$ & Cynopsis - May 26, 2010 \\
\hline Medium, CBS & $21 / 01 / 2011$ & $4.9 \%$ & $9 \%$ & $4.9 \%$ & $9 \%$ & Cynopsis - January 25, 2011 \\
\hline Brothers \& Sisters, ABC & 08/05/2011 & $4.9 \%$ & $8 \%$ & $4.9 \%$ & $8 \%$ & Cynopsis - May 21, 2011 \\
\hline Smallville, CW & $13 / 05 / 2011$ & $1.8 \%$ & $3 \%$ & $1.8 \%$ & $3 \%$ & Cynopsis - May 17, 2011 \\
\hline Desperate Housewives, $A B C$ & $13 / 05 / 2012$ & $9.0 \%$ & $14 \%$ & $6.9 \%$ & $11 \%$ & Cynopsis - May 16, 2012 \\
\hline
\end{tabular}

Notes:

${ }^{a}$ The Evening Independent - Feb 26, 1986 


\section{Online Appendix B - Supplementary material}

\section{Placebo Tests and the Effects of a Loss of Sleep}

The evidence put forward in the communication literature suggests that it is the actual end of TV shows that generates negative emotional reactions in viewers [e.g. Eyal and Cohen, 2006]. Consequently, if the correlation between TV series finales and stock returns documented above is really caused by the wave of negative mood resulting from a parasocial breakup, then one should not observe any abnormal stock return patterns immediately following the series episodes that precede the finale. ${ }^{26}$ As a placebo test, I therefore shift the times series of the TV show finales back by seven days (TV series episodes typically air once a week, on the same day of the week, and at the same time), and I re-estimate equation (3) accordingly. The regression output (not reported here) shows that, immediately following the next to last episode of a series, $\beta_{1}$ and $\beta_{2}$ are estimated to be close to zero and are statistically insignificant (individually and jointly) for all indices. I obtain analogous results when shifting the times series of the TV show finales back by fourteen days or forward by seven days. This suggests that the empirical pattern presented in the previous sections is not caused by any calendar anomalies pertaining to the periodicity of the TV shows in the sample or by the fact that viewers are exposed to the content (e.g. happy, sad) of such shows, per se, but rather by the fact that said shows ended their run.

According to the regular surveys conducted by the National Sleep Foundation, watching TV is the most common activity within one hour of going to bed [NSF, 2010], and comedies and dramas are the most watched types of shows before going to sleep [NSF, 2011]. Since the most popular TV series air in the evening, one could be concerned that viewers experience a loss of sleep

\footnotetext{
${ }^{26}$ I thank an anonymous reviewer for suggesting this approach. Viewers may also have a negative reaction when they learn that they may experience the loss of a parasocial relationship [Cohen, 2003; 2004]; however, I could not obtain any systematic data on the dates when the American public became aware of the impending end of the series in the sample.
} 
as a result of staying up late to watch the final episodes of their favorite shows. In turn, a reduced amount of sleep may affect their decisions on the following day. ${ }^{27}$ Indeed, there is plenty of evidence that substantial sleep loss can affect cognitive performance, mood [e.g. Durmer and Dinges, 2005], and next day preference for demanding tasks [Engle-Friedman et al. 2003]. In the financial realm, Kamstra et al. [2000] document that daylight saving time changes are immediately followed by lower-than-average stock returns, suggesting that the loss (or gain) of an hour of sleep has a negative impact on the demand for risky assets. Given these insights and the evidence presented in the previous sections, one may therefore conjecture a larger decrease in stock returns following highly popular finales that are broadcast late at night and may cause a loss of sleep in a large number of viewers.

To investigate this hypothesis, I collected data about the air times of the series finales in the sample from the historical archive hosted by tvtango.com. ${ }^{28}$ The vast majority of the finales ended by or at 10PM, one ended at 10:30PM, 37 at 11PM, and one after midnight. In terms of sleep behavior, on weeknights (weekends) only about 14\% (4\%) of 18-54 year-old Americans usually goes to bed before 10PM, whereas about 44\% (18\%) goes to bed before 11PM [NSF, 2003]. Since the finales that ended after 10PM may have caused at least a minor sleep loss in a sizable portion of the population, I estimate a modified version of model (3) with two additional interaction terms, as follows:

$$
\begin{aligned}
r_{t}= & \alpha+\beta_{1} \text { FINALE }_{t-1}+\beta_{2} \text { FINALE }_{t-1} \times \ln \left(\text { VIEWERS }_{t-1}\right)+\beta_{3} \text { FINALE }_{t-1} \times \text { LATE }_{t-1}+ \\
& +\beta_{4} \text { FINALE }_{t-1} \times \ln \left(\operatorname{VIEWERS~}_{t-1}\right) \times \operatorname{LATE}_{t-1}+\Psi \mathrm{X}_{t}+\varepsilon_{t}
\end{aligned}
$$

where $L A T E_{t-1}$ is a dummy variable that takes value 1 if the corresponding series finale ended after 10PM and 0 otherwise, and $\mathbf{X}_{\mathrm{t}}$ is a vector of all the control variables appearing in model (3). The

\footnotetext{
${ }^{27}$ I thank an anonymous reviewer for suggesting this mechanism.

${ }^{28}$ Airing times were missing for a handful of series. By inspecting several issues of the magazine Broadcasting \& Cable I was able to fill in some of the missing data, so that in the final sample there are only three missing observations.
} 
regression output (not reported here) reveals that $\beta_{1}$ and $\beta_{2}$ maintain their signs and statistical significance. For all market indices, the coefficient $\beta_{3}$ is estimated to be positive and, consistently with the sleep loss argument, $\beta_{4}$ is estimated to be negative (i.e. a given increase in the number of viewers watching a series finale has a stronger negative effect on next-day stock returns when the finale airs late at night). However, both $\beta_{3}$ and $\beta_{4}$ are not statistically different from zero at conventional levels. One possible explanation for this result is that the tests on these two coefficients have little statistical power, as the number of late-night finales is small (39 cases). Moreover, the sleep loss caused by the series finales may not be large enough to have a detectible impact on individuals' decisions. Notwithstanding the lack of statistical significance, the sign of the coefficient of interest is consistent with the findings of Kamstra et al. [2000] and seems to support the overall story told in this study.

\section{Additional Robustness Tests}

One may wonder whether the TV show finale effect highlighted above is merely the result of few extremely popular finales that are followed by sizable negative stock returns. To address this issue, I construct a dummy variable that takes value 1 on trading days that immediately follow the ten most popular series finales in the sample (in terms of number of TV viewers) and 0 otherwise. I then re-estimate regression model (3) after adding this further dummy indicator to the equation. The resulting estimates are shown in Table B.1 (panel A) and reveal that, for all five market indices, the signs and statistical significance of $\beta_{1}$ and $\beta_{2}$ are not affected by this procedure, while their magnitudes are only marginally altered.

As an alternative, I rank all post-finale trading days based on their realized stock returns (from largest to smallest) and construct a dummy variable that takes value 1 on the ten post-finale trading days with the smallest returns. I then re-estimate model (3) with this additional dummy 
variable. The results, displayed in Table B.1 (panel B), confirm that the signs, magnitudes, and statistical significance of $\beta_{1}$ and $\beta_{2}$ are not sensitive to this treatment. I obtain virtually identical results (see panel C) when I simply exclude these ten observations from the sample instead of using the above-mentioned dummy variable approach.

In order to analyze the stability of $\beta_{1}$ and $\beta_{2}$ over time, I also divide the sample into two subsamples, each containing approximately half of the TV show finale events. I then re-estimate model (3) using each of the two sub-samples, separately. The estimates, shown in Table B.2, suggest that, for all five market indices, the sign patterns of the two coefficients are exactly the same across the two sub-periods analyzed. Their magnitudes are also consistent to a high degree across the two subsamples. When the first sub-period is analyzed, $\beta_{1}$ and $\beta_{2}$ are individually and jointly statistically significant at least at the $5 \%$ level across the five market indices. In the second sub-period, at the individual level the two coefficients are statistically significant at the 5\% level in two cases (Nasdaq and Russell 2000) and approach significance in the remaining cases; when considered jointly, they approach statistical significance in two instances (Nasdaq and Russell 2000). Given that a loss of statistical power is to be expected when halving the sample and reducing considerably the number of relevant events, and given that $\beta_{1}$ and $\beta_{2}$ 's patterns are highly consistent across the two subperiods, the sub-sample analysis suggests that these two coefficients feature a substantial degree of stability. This brings again some support to the mood hypothesis that is the focus of this study.

In a further robustness exercise, I explicitly address the possibility of heteroskedaticity in the error term of the regression equation by jointly modeling the conditional mean and volatility of stock returns. Since stock returns tend to exhibit GARCH-type behavior, I employ the following GARCH(1,1) model:

$$
\begin{aligned}
r_{t}= & \alpha+\beta_{1} \text { FINALE }_{t-1}+\beta_{2} \text { FINALE }_{t-1} \times \ln \left(\text { VIEWERS }_{t-1}\right)+\lambda_{1} F A L L_{t}+\lambda_{2} S A D_{t}+ \\
& +\lambda_{3} \text { NEWMOON }_{t}+\lambda_{4} \text { FULLMOON }_{t}+\lambda_{5} \text { TEMP }_{t}+\lambda_{6} \text { WIND }_{t}+\lambda_{7} \text { RAIN }_{t}+\omega_{1} r_{t-1}+
\end{aligned}
$$




$$
\begin{aligned}
& \quad+\omega_{2} \operatorname{TPRE}_{t-1}+\sum_{j=1}^{11} \mu_{j} \text { MACRO }_{j t}+\gamma_{1} \operatorname{PRE}_{t}+\gamma_{2} \operatorname{POST}_{t}+\sum_{n=1}^{4} \delta_{n} D W_{n t}+\sum_{k=1}^{11} \eta_{k} D M_{k t}+\varepsilon_{t} \\
& \varepsilon_{t}=\sigma_{t} z_{t} \\
& \sigma_{t} \sim \operatorname{NID}(0,1) \\
& =\varphi_{0}+\varphi_{1} \varepsilon_{t-1}+\varphi_{2} \sigma_{t-1}^{2}
\end{aligned}
$$

To perform statistical inference I compute robust standard errors using the Huber-White sandwich robust estimator of variance [Huber, 1967; White, 1980]. The estimates, reported in Table B.3, show that $\beta_{1}$ and $\beta_{2}$ are individually statistically significant at conventional levels for most market indices, and their magnitudes are qualitatively similar to the ones obtained from model (3). The joint tests reject the null hypothesis that the two coefficients are equal to zero at least at the 5\% significance level in three instances, whereas significance is approached in the case of the Russell $2000(p$-value $=0.055) .{ }^{29}$ The remaining explanatory variables exhibit patterns that resemble the ones I obtained from model (3), with $P R E$ and WIND having positive and generally statistically significant coefficients and RAIN and FALL having negative and at times significant coefficients.

Lastly, one may wonder whether the TV series finale effect documented above is caused by changes in market liquidity. If people are busy watching their favorite show's finale on TV and discussing the content of the finale with their friends/coworkers/acquaintances on the following day, then they have less time for pondering trading decisions. If enough individuals choose to not participate in the stock market on the post-finale trading day, then the diminished order flow and amplified execution time might tempt sellers to agree to a lower price [Edmands et al., 2007]. To address this concern, I examine the time series of aggregate trading volume for the U.S. stock

\footnotetext{
${ }^{29}$ I obtained virtually identical results when using a GARCH-in-mean model.
} 
market. ${ }^{30}$ The first step consists in detrending the trading volume series, which I accomplish using a formula inspired by Chuang and Lee [2006]:

$$
D V_{t}=\ln \left(V O L U M E_{t}\right)-\frac{1}{63} \sum_{n=-64}^{-1} \ln \left(V O L U M E_{t+n}\right)
$$

I then use $D V_{t}$ as the dependent variable in regression equation (3). ${ }^{31}$ The results, displayed in Table B.4, reveal that trading volume decreases around the holidays, rises in the fall season, and rises when major macroeconomic announcements are made (the coefficients on the announcement dummies are not shown in the table due to space constraints). However, the point estimates of $\beta_{1}$ and $\beta_{2}$ are close to zero, and the two coefficients are statistically insignificant (individually and jointly) at conventional levels, which suggests that there is no evidence that the TV series finale effect is the result of an abnormal pattern in market liquidity. ${ }^{32}$

\footnotetext{
${ }^{30}$ I obtained the relevant data from Datastream. I employ two different measures that refer to the number of constituent shares traded (code: TOTMKUS(VO)) and the number of shares traded multiplied by the closing price for each stock (code: TOTMKUS(VA)), respectively. See Table 2, Panel B, for some summary statistics.

${ }^{31}$ An augmented Dickey-Fuller test (with five lagged differences and a constant) rejects the null hypothesis that the detrended series contains a unit root at the $1 \%$ confidence level.

${ }^{32}$ I obtained analogous results when using either a 22-day (one month) or 126-day (six months) moving average in formula (6) to detrend the trading volume time series.
} 
Table B.1

TV Series Finales and Stock Returns - Sensitivity to Outliers

This table displays the coefficient estimates generated by fitting an augmented version of regression model (3) that includes a dummy for potential outliers. In panel A the dummy takes value 1 on trading days that immediately follow the ten most watched TV series finales in the sample (in millions of viewers), and 0 otherwise. In panel B the dummy takes value 1 on the ten post-finale trading days exhibiting the lowest stock returns among the post-finale trading days, and 0 otherwise. In panel $\mathrm{C}$ the ten post-finale trading days featuring the lowest stock returns are dropped from the sample. The coefficients on the remaining explanatory variables in equation (3) are not reported due to space limitations. $p$-values computed using Newey-West robust standard errors are shown in square brackets below the corresponding coefficients. The last row in each panel reports the $p$-values relative to the null hypothesis that the two coefficients of interest $\left(\beta_{1}\right.$ and $\left.\beta_{2}\right)$ are jointly equal to zero. One, two, and three asterisks denote statistical significance at the ten, five, and one percent level, respectively.

\begin{tabular}{llllll} 
Dep. Var.: & $\begin{array}{c}\text { Nasdaq } \\
\text { Comp }\end{array}$ & $\begin{array}{c}\text { NYSE } \\
\text { Comp }\end{array}$ & S\&P500 & Russell 3000 & Russell 2000 \\
\cline { 2 - 5 }
\end{tabular}

(1) (2) $\quad(2)$

(2)

(3)

(4)

(5)

\begin{tabular}{|c|c|c|c|c|c|}
\hline Panel A & & & & & \\
\hline$\beta_{1}$ FINALE & $\begin{array}{c}1.603 * * * \\
{[0.003]}\end{array}$ & $\begin{array}{l}1.147 * * \\
{[0.031]}\end{array}$ & $\begin{array}{l}1.217 * * \\
{[0.014]}\end{array}$ & $\begin{array}{l}1.266^{* * *} \\
{[0.013]}\end{array}$ & $\begin{array}{l}1.464 * * \\
{[0.020]}\end{array}$ \\
\hline$\beta_{2}$ FINALEx $\times \ln (\mathrm{VIEWERS})$ & $\begin{array}{c}-.598 * * * \\
{[0.005]}\end{array}$ & $\begin{array}{l}-.389 * * \\
{[0.048]}\end{array}$ & $\begin{array}{l}-.415 * * \\
{[0.026]}\end{array}$ & $\begin{array}{l}-.454 * * \\
{[0.019]}\end{array}$ & $\begin{array}{l}-.535^{* *} \\
{[0.022]}\end{array}$ \\
\hline $\begin{array}{c}\text { Joint significance test }\left(\beta_{1}=\beta_{2}=0\right) \\
p \text {-value: }\end{array}$ & $0.013^{* *}$ & $0.055^{*}$ & $0.023^{* *}$ & $0.038 * *$ & $0.067 *$ \\
\hline
\end{tabular}

\begin{tabular}{lccccc}
\hline Panel B & & & & \\
\hline$\beta_{1}$ FINALE & $1.397 * * *$ & $1.099 * * *$ & $.992 * *$ & $1.096 * * *$ & $1.461 * * *$ \\
& {$[0.001]$} & {$[0.009]$} & {$[0.016]$} & {$[0.007]$} & {$[0.003]$} \\
$\beta_{2}$ FINALEx $\ln ($ VIEWERS) & $-.419 * * *$ & $-.306 * *$ & $-.264 *$ & $-.329 * *$ & $-.463 * * *$ \\
$\begin{array}{c}\text { Joint significance test }\left(\beta_{1}=\beta_{2}=0\right) \\
p \text {-value: }\end{array}$ & {$[0.004]$} & {$[0.040]$} & {$[0.074]$} & {$[0.023]$} & {$[0.006]$} \\
$\quad 0.001 * * *$ & $0.001 * * *$ & $0.001 * * *$ & $0.004 * * *$ & $0.007 * * *$
\end{tabular}

\begin{tabular}{lccccc}
\hline Panel C & & & & \\
\hline$\beta_{1}$ FINALE & $1.352 * * *$ & $1.193 * * *$ & $1.048 * *$ & $1.151 * * *$ & $1.515 * * *$ \\
& {$[0.002]$} & {$[0.008]$} & {$[0.014]$} & {$[0.007]$} & {$[0.004]$} \\
$\beta_{2}$ FINALExln(VIEWERS) & $-.402 * * *$ & $-.343 * *$ & $-.286^{*}$ & $-.351 * *$ & $-.484 * * *$ \\
$\begin{array}{c}\text { Joint significance test }\left(\beta_{1}=\beta_{2}=0\right) \\
p \text {-value: }\end{array}$ & {$[0.007]$} & {$[0.031]$} & {$[0.065]$} & {$[0.021]$} & {$[0.007]$} \\
$\quad 0.002 * * *$ & $0.001 * * *$ & $0.001 * * *$ & $0.004 * * *$ & $0.008 * * *$ \\
\hline \hline
\end{tabular}


Table B.2

TV Series Finales and Stock Returns - Sub-sample Analysis

This table displays the coefficient estimates generated by fitting regression model (3) after splitting the sample into two sub-samples that contain approximately the same number of event days. Panel A shows the estimates for the less recent sub-sample, and panel B contains the estimates for the more recent sub-sample. The coefficients on the remaining explanatory variables in equation (3) are not reported due to space limitations. $p$-values computed using Newey-West robust standard errors are shown in square brackets below the corresponding coefficients. The last row in each panel reports the $p$-values relative to the null hypothesis that the two coefficients of interest $\left(\beta_{1}\right.$ and $\left.\beta_{2}\right)$ are jointly equal to zero. One, two, and three asterisks denote statistical significance at the ten, five, and one percent level, respectively.

\begin{tabular}{|c|c|c|c|c|c|}
\hline Dep. Var.: & $\begin{array}{l}\text { Nasdaq } \\
\text { Comp }\end{array}$ & $\begin{array}{l}\text { NYSE } \\
\text { Comp }\end{array}$ & S\&P500 & Russell 3000 & Russell 2000 \\
\hline & (1) & (2) & (3) & (4) & (5) \\
\hline Panel A: Sub-sample 1 & $\begin{array}{l}8 / 2 / 1971- \\
5 / 31 / 2001\end{array}$ & $\begin{array}{l}1 / 4 / 1967- \\
5 / 31 / 2001\end{array}$ & $\begin{array}{l}1 / 4 / 1967- \\
5 / 31 / 2001\end{array}$ & $\begin{array}{l}\text { 9/11/1987- } \\
5 / 31 / 2001 \\
\end{array}$ & $\begin{array}{l}\text { 9/11/1987- } \\
5 / 31 / 2001 \\
\end{array}$ \\
\hline$\beta_{1}$ FINALE & $\begin{array}{c}1.714 * * * \\
{[0.008]}\end{array}$ & $\begin{array}{c}1.250 * * * \\
{[0.008]}\end{array}$ & $\begin{array}{l}1.363 * * \\
{[0.011]}\end{array}$ & $\begin{array}{c}1.594 * * * \\
{[0.001]}\end{array}$ & $\begin{array}{c}1.435 * * * \\
{[0.001]}\end{array}$ \\
\hline$\beta_{2}$ FINALE $\times \ln ($ VIEWERS $)$ & $\begin{array}{c}-.555 * * * \\
{[0.007]}\end{array}$ & $\begin{array}{l}-.370 * * \\
{[0.026]}\end{array}$ & $\begin{array}{l}-.407 * * \\
{[0.031]}\end{array}$ & $\begin{array}{l}-.535 * * * \\
{[0.001]}\end{array}$ & $\begin{array}{c}-.492 * * * \\
{[0.001]}\end{array}$ \\
\hline $\begin{array}{l}\text { Joint significance test }\left(\beta_{1}=\beta_{2}=0\right) \\
p \text {-value: }\end{array}$ & $0.025 * *$ & $0.002 * * *$ & $0.005 * * *$ & $0.001 * * *$ & $0.001 * * *$ \\
\hline Observations & 7560 & 8530 & 8558 & 3452 & 3531 \\
\hline Panel B: Sub-sample 2 & $\begin{array}{l}6 / 1 / 2001- \\
8 / 31 / 2012\end{array}$ & $\begin{array}{l}6 / 1 / 2001- \\
8 / 31 / 2012\end{array}$ & $\begin{array}{l}6 / 1 / 2001- \\
8 / 31 / 2012\end{array}$ & $\begin{array}{l}6 / 1 / 2001- \\
8 / 31 / 2012\end{array}$ & $\begin{array}{l}6 / 1 / 2001- \\
8 / 31 / 2012\end{array}$ \\
\hline$\beta_{1}$ FINALE & $\begin{array}{l}1.423 * * \\
{[0.034]}\end{array}$ & $\begin{array}{l}1.328^{*} \\
{[0.064]}\end{array}$ & $\begin{array}{l}1.240 * \\
{[0.056]}\end{array}$ & $\begin{array}{l}1.298 * \\
{[0.051]}\end{array}$ & $\begin{array}{l}1.823 * * \\
{[0.031]}\end{array}$ \\
\hline$\beta_{2}$ FINALE $\times \ln ($ VIEWERS $)$ & $\begin{array}{l}-.561 * * \\
{[0.046]}\end{array}$ & $\begin{array}{l}-.513 * \\
{[0.080]}\end{array}$ & $\begin{array}{l}-.460 * \\
{[0.086]}\end{array}$ & $\begin{array}{l}-.488 * \\
{[0.076]}\end{array}$ & $\begin{array}{l}-.725 * * \\
{[0.039]}\end{array}$ \\
\hline $\begin{array}{c}\text { Joint significance test }\left(\beta_{1}=\beta_{2}=0\right) \\
p \text {-value: }\end{array}$ & 0.101 & 0.169 & 0.124 & 0.124 & $0.096^{*}$ \\
\hline Observations & 2831 & 2831 & 2831 & 2831 & 2831 \\
\hline
\end{tabular}


Table B.3

TV Series Finales and Stock Returns - GARCH Model

This table displays the coefficient estimates generated by fitting model (5). An X marks the controls that are included in the model but whose coefficients are not reported here due to space limitations. $p$-values computed using Huber-White robust standard errors are shown in square brackets below the corresponding coefficients. The last row reports the $p$ values relative to the null hypothesis that the two coefficients of interest $\left(\beta_{1}\right.$ and $\left.\beta_{2}\right)$ are jointly equal to zero. One, two, and three asterisks denote statistical significance at the ten, five, and one percent level, respectively.

\begin{tabular}{|c|c|c|c|c|c|}
\hline Dep. Var.: & $\begin{array}{l}\text { Nasdaq } \\
\text { Comp }\end{array}$ & $\begin{array}{l}\text { NYSE } \\
\text { Comp }\end{array}$ & S\&P500 & Russell 3000 & Russell 2000 \\
\hline & (1) & (2) & (3) & (4) & $(5)$ \\
\hline$\alpha$ & $\begin{array}{c}.097 \\
{[0.634]}\end{array}$ & $\begin{array}{c}.141 \\
{[0.408]}\end{array}$ & $\begin{array}{c}.116 \\
{[0.520]}\end{array}$ & $\begin{array}{c}109 \\
{[0.676]}\end{array}$ & $\begin{array}{c}-.125 \\
{[0.649]}\end{array}$ \\
\hline$\beta_{1}$ FINALE & $\begin{array}{c}.673^{*} \\
{[0.076]}\end{array}$ & $\begin{array}{l}.962 * * \\
{[0.014]}\end{array}$ & $\begin{array}{l}.920 * * \\
{[0.014]}\end{array}$ & $\begin{array}{c}1.023 * * * \\
{[0.002]}\end{array}$ & $\begin{array}{l}1.089 * * \\
{[0.023]}\end{array}$ \\
\hline$\beta_{2}$ FINALExIn(VIEWERS) & $\begin{array}{c}-.219^{*} \\
{[0.095]}\end{array}$ & $\begin{array}{l}-.300^{* *} \\
{[0.027]}\end{array}$ & $\begin{array}{l}-.285^{* *} \\
{[0.030]}\end{array}$ & $\begin{array}{c}-.357 * * * \\
{[0.002]}\end{array}$ & $\begin{array}{l}-.379 * * \\
{[0.017]}\end{array}$ \\
\hline FALL & $\begin{array}{l}-.106 * * \\
{[0.027]}\end{array}$ & $\begin{array}{c}-.067^{*} \\
{[0.097]}\end{array}$ & $\begin{array}{c}-.066 \\
{[0.126]}\end{array}$ & $\begin{array}{c}-.107^{*} \\
{[0.071]}\end{array}$ & $\begin{array}{l}-.133 * * \\
{[0.031]}\end{array}$ \\
\hline SAD & $\begin{array}{c}.031 \\
{[0.597]}\end{array}$ & $\begin{array}{c}-.021 \\
{[0.679]}\end{array}$ & $\begin{array}{c}-.026 \\
{[0.631]}\end{array}$ & $\begin{array}{c}.021 \\
{[0.797]}\end{array}$ & $\begin{array}{c}.128 \\
{[0.136]}\end{array}$ \\
\hline NEWMOON & $\begin{array}{c}-.027 \\
{[0.264]}\end{array}$ & $\begin{array}{c}.005 \\
{[0.855]}\end{array}$ & $\begin{array}{c}.002 \\
{[0.932]}\end{array}$ & $\begin{array}{c}-.011 \\
{[0.731]}\end{array}$ & $\begin{array}{c}-.010 \\
{[0.761]}\end{array}$ \\
\hline FULLMOON & $\begin{array}{c}-.006 \\
{[0.797]}\end{array}$ & $\begin{array}{c}.004 \\
{[0.855]}\end{array}$ & $\begin{array}{c}.012 \\
{[0.613]}\end{array}$ & $\begin{array}{c}.025 \\
{[0.481]}\end{array}$ & $\begin{array}{c}-.003 \\
{[0.929]}\end{array}$ \\
\hline TEMP & $\begin{array}{c}.001 \\
{[0.958]}\end{array}$ & $\begin{array}{c}.001 \\
{[0.970]}\end{array}$ & $\begin{array}{c}.001 \\
{[0.767]}\end{array}$ & $\begin{array}{c}-.001 \\
{[0.805]}\end{array}$ & $\begin{array}{c}-.001 \\
{[0.676]}\end{array}$ \\
\hline WIND & $\begin{array}{l}.007 * * \\
{[0.032]}\end{array}$ & $\begin{array}{l}.007 * * * \\
{[0.010]}\end{array}$ & $\begin{array}{l}.008 * * * \\
{[0.007]}\end{array}$ & $\begin{array}{c}.006 \\
{[0.111]}\end{array}$ & $\begin{array}{c}.005 \\
{[0.255]}\end{array}$ \\
\hline RAIN & $\begin{array}{l}-.044 * * \\
{[0.032]}\end{array}$ & $\begin{array}{c}-.029 \\
{[0.133]}\end{array}$ & $\begin{array}{c}-.035^{*} \\
{[0.080]}\end{array}$ & $\begin{array}{c}-.038 \\
{[0.195]}\end{array}$ & $\begin{array}{c}-.053^{*} \\
{[0.079]}\end{array}$ \\
\hline$r_{t-1}$ & $\begin{array}{l}.145^{* * * *} \\
{[0.001]}\end{array}$ & $\begin{array}{l}.121 * * * \\
{[0.001]}\end{array}$ & $\begin{array}{l}.078 * * * \\
{[0.001]}\end{array}$ & $\begin{array}{c}.026 \\
{[0.356]}\end{array}$ & $\begin{array}{l}.073 * * \\
{[0.022]}\end{array}$ \\
\hline TPRE & $\begin{array}{c}-.006 \\
{[0.504]}\end{array}$ & $\begin{array}{c}-.001 \\
{[0.872]}\end{array}$ & $\begin{array}{c}.001 \\
{[0.866]}\end{array}$ & $\begin{array}{l}-.023 * * \\
{[0.039]}\end{array}$ & $\begin{array}{c}-.004 \\
{[0.731]}\end{array}$ \\
\hline Macro Announcements & $\mathrm{X}$ & $\mathrm{X}$ & $\mathrm{X}$ & $\mathrm{X}$ & $\mathrm{X}$ \\
\hline PRE & $\begin{array}{l}.111 * * * \\
{[0.004]}\end{array}$ & $\begin{array}{l}.111 * * * \\
{[0.004]}\end{array}$ & $\begin{array}{l}.089 * * \\
{[0.037]}\end{array}$ & $\begin{array}{c}-.057 \\
{[0.359]}\end{array}$ & $\begin{array}{c}.095^{*} \\
{[0.072]}\end{array}$ \\
\hline POST & $\begin{array}{c}-.072 \\
{[0.290]}\end{array}$ & $\begin{array}{c}.026 \\
{[0.645]}\end{array}$ & $\begin{array}{c}.039 \\
{[0.519]}\end{array}$ & $\begin{array}{c}.048 \\
{[0.580]}\end{array}$ & $\begin{array}{c}.002 \\
{[0.982]}\end{array}$ \\
\hline Weekday \& Month Dummies & $\mathrm{X}$ & $\mathrm{X}$ & $\mathrm{X}$ & $\mathrm{X}$ & $\mathrm{X}$ \\
\hline Observations & 10391 & 11361 & 11389 & 6283 & 6362 \\
\hline Wald $\chi^{2}$ & $139.3 * * *$ & $116.1 * * *$ & $87.0 * * *$ & $57.9 * *$ & $66.9^{* * *}$ \\
\hline $\begin{array}{c}\text { Joint significance test }\left(\beta_{1}=\beta_{2}=0\right) \\
p \text {-value: }\end{array}$ & 0.203 & $0.036^{* *}$ & $0.029 * *$ & $0.009 * * *$ & $0.055^{*}$ \\
\hline
\end{tabular}


Table B.4

TV Series Finales and Trading Volume

This table displays the coefficient estimates generated by fitting a modified version of model (3), where the original dependent variable is replaced with the detrended trading volume for U.S. stocks. Daily trading volume is detrended using formula (6). Two measures of trading volume are employed: the number of constituent shares traded (column 1) and the number of shares traded multiplied by the closing price of each stock (column 2 ). The one-day lagged return to the $S \& P 500$ index is used as a control variable. An $X$ marks the controls that are included in the model but whose coefficients are not reported here due to space limitations. $p$-values computed using Newey-West robust standard errors are shown in square brackets below the corresponding coefficients. The last row reports the $p$-values relative to the null hypothesis that the two coefficients of interest $\left(\beta_{1}\right.$ and $\left.\beta_{2}\right)$ are jointly equal to zero. One, two, and three asterisks denote statistical significance at the ten, five, and one percent level, respectively.

\begin{tabular}{|c|c|c|}
\hline Dep. Var.: & $\begin{array}{c}\text { U.S. Market } \\
\text { Detrended Trading Volume } \\
\text { (\# of shares traded) }\end{array}$ & $\begin{array}{c}\text { U.S. Market } \\
\text { Detrended Trading Volume } \\
(\# \text { of shares } \times \text { closing price) }\end{array}$ \\
\hline & (1) & (2) \\
\hline$\alpha$ & $\begin{array}{l}-.098 * * \\
{[0.039]}\end{array}$ & $\begin{array}{c}-.127 * * \\
{[0.012]}\end{array}$ \\
\hline$\beta_{1}$ FINALE & $\begin{array}{c}-.045 \\
{[0.343]}\end{array}$ & $\begin{array}{c}-.026 \\
{[0.586]}\end{array}$ \\
\hline$\beta_{2}$ FINALE $\times \ln ($ VIEWERS $)$ & $\begin{array}{c}.014 \\
{[0.463]}\end{array}$ & $\begin{array}{c}.009 \\
{[0.633]}\end{array}$ \\
\hline FALL & $\begin{array}{c}.117 * * * \\
{[0.001]}\end{array}$ & $\begin{array}{c}.125 * * * \\
{[0.001]}\end{array}$ \\
\hline SAD & $\begin{array}{c}.005 \\
{[0.705]}\end{array}$ & $\begin{array}{c}.004 \\
{[0.776]}\end{array}$ \\
\hline NEWMOON & $\begin{array}{c}-.007 \\
{[0.345]}\end{array}$ & $\begin{array}{c}-.008 \\
{[0.351]}\end{array}$ \\
\hline FULLMOON & $\begin{array}{c}-.001 \\
{[0.964]}\end{array}$ & $\begin{array}{c}-.001 \\
{[0.985]}\end{array}$ \\
\hline TEMP & $\begin{array}{c}.001 \\
{[0.204]}\end{array}$ & $\begin{array}{c}.001 * \\
{[0.061]}\end{array}$ \\
\hline WIND & $\begin{array}{c}.001 \\
{[0.956]}\end{array}$ & $\begin{array}{c}-.001 \\
{[0.775]}\end{array}$ \\
\hline RAIN & $\begin{array}{c}-.002 \\
{[0.658]}\end{array}$ & $\begin{array}{c}-.003 \\
{[0.644]}\end{array}$ \\
\hline$r_{t-1}$ & $\begin{array}{l}.007 * * \\
{[0.027]}\end{array}$ & $\begin{array}{l}.013 * * * \\
{[0.001]}\end{array}$ \\
\hline TPRE & $\begin{array}{c}-.003 \\
{[0.223]}\end{array}$ & $\begin{array}{c}.001 \\
{[0.881]}\end{array}$ \\
\hline Macro Announcements & $X$ & $\mathrm{X}$ \\
\hline PRE & $\begin{array}{c}-.224 * * * \\
{[0.001]}\end{array}$ & $\begin{array}{c}-.231 * * * \\
{[0.001]}\end{array}$ \\
\hline POST & $\begin{array}{c}-.253 * * * \\
{[0.001]}\end{array}$ & $\begin{array}{c}-.254 * * * \\
{[0.001]}\end{array}$ \\
\hline Weekday \& Month Dummies & $X$ & $X$ \\
\hline Observations & 9860 & 9860 \\
\hline F stat & $37.66 * * *$ & $37.83 * * *$ \\
\hline $\begin{array}{c}\text { Joint significance test }\left(\beta_{1}=\beta_{2}=0\right) \\
p \text {-value: }\end{array}$ & 0.558 & 0.857 \\
\hline
\end{tabular}

